\title{
The Harms CaUSed: A NarRative OF INTERGENERATIONAL RESPONSIBILITY
}

\author{
MAEGAN HOUGH ${ }^{*}$
}

Born out of the Indian Residential Schools Settlement Agreement, the Independent Assessment Process is a program that provides monetary compensation to former students who suffered sexual and physical abuse at Indian Residential Schools. As "Canada's Representative" during hearings of the Independent Assessment Process, this author, a young lawyer at the time, bore witness to grizzly accounts of acts perpetrated against claimants that left her unsettled. Unsettled by what was heard, yes, but also in her observations that the process did not satisfy the needs of all claimants, nor did it engage with her own sense of responsibility as a non-Indigenous Canadian.

The author weaves together her experiences and observations as "Canada's Representative" to explore intergenerational justice in a Canadian setting, and what processes might offer a more complete approach in handling the Indian Residential Schools legacy. First, she canvasses the existing framework of dispute settlement in the context of Indian Residential Schools, namely criminal, tort, and alternative dispute resolution mechanisms. While pointing out the strengths these mechanisms do have to address some of the harms of Indian Residential Schools, she ultimately suggests their inherent legal limitations make them inadequate tools to provide redress to victims and engage society more broadly.

The author goes on to define transitional justice, set out its established tenets and themes, and begins to map out a Canadian application of these principles to the Indian Residential Schools policy by drawing on examples from Australia, New Zealand, and the United States. These principles take shape as innovative instruments for advancing the goals of reconciliation and of Canadian society. They are not without their own flaws, however, as the author also points out, that may affect how Canadians-in particular, non-Indigenous Canadians-view their legitimacy.

Lastly, the author analyzes prevailing views of societal responsibility to provide a normative underpinning for intergenerational justice in a Canadian context. She concludes by advocating Canadians move from a stance of guilt and blame toward one of a broad assumption of responsibility as they continue to grapple with the legacy of Indian Residential Schools.

\section{TABLE OF CONTENTS}

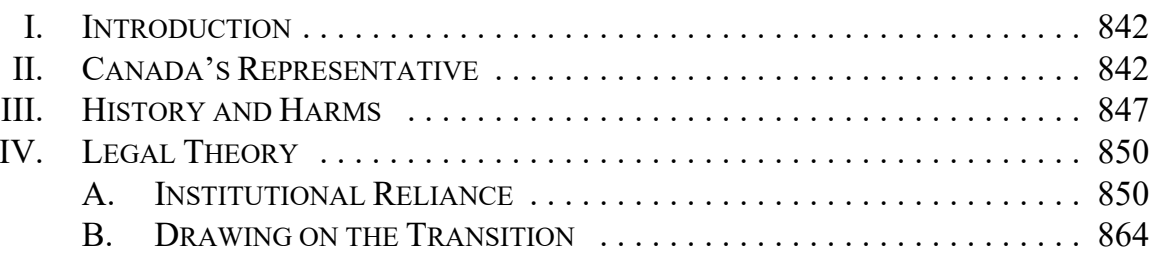

Legal Counsel, Department of Justice Canada. The views and opinions expressed in this article are entirely those of the author and do not reflect those of the Department of Justice or the Government of Canada. This article is adapted from my LLM Thesis completed under the thoughtful guidance of Professors Jeremy Webber and Matt James at the University of Victoria and with financial support from the Social Sciences and Humanities Research Council of Canada. Additional thanks are due to Professor Hadley Friedland and Dr. Ron Stevenson for their constant encouragement, to Hannah Wyile for her keen eyes, and to the editors and anonymous peer reviewers for their insightful suggestions. All errors or omissions are my own. 
V. LOCATING RESPONSIBILITY $\ldots \ldots \ldots \ldots \ldots \ldots \ldots \ldots \ldots$

A. SYSTEMIC RESPONSIBILITY . . . . . . . . . . . . . . . . . . . . . 874

B. RESPONSIBILITY FOR THE PAST $\ldots \ldots \ldots \ldots \ldots \ldots \ldots \ldots \ldots$

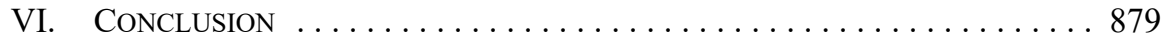

I call on all Canadians - elders and youth, Aboriginal or not - to commit to reconciliation and breaking down the wall of indifference. This is not just a dream, it is a collective responsibility.

— Rt. Hon. Michaëlle Jean ${ }^{1}$

\section{INTRODUCTION}

In this article I explore the Canadian legal system through the prism of my personal experience acting as Canada's Representative at Independent Assessment Process (IAP) hearings. I target my own discomfort in working within a legal system that did not appear at all responsive to the experience of many of the actors in IAP hearings, in particular to certain types of harms experienced by the claimants.

After setting out this experience I identify the full range of harms brought forward by claimants in order to analyze them more systematically. I then set out in some detail the major dispute resolution processes available in Canada to address harms, both "traditional" and "alternative," considering along the way their ability to address the harms identified at the outset.

I conclude that there is no single mechanism that is currently able to address the full range of harms I heard at IAP hearings. In the balance of the article I therefore search out and propose a new framework for addressing harm, one that focuses on the responsibility of actors within a polity and across its generations. In doing so I place myself and all contemporary citizens in a position of agency over our shared history, present, and future.

\section{Canada's Representative}

In early 2009, I attended my first IAP hearing as an observer. The week before I had been trained on Schedule D of the Indian Residential Schools Settlement Agreement, ${ }^{2}$ and Canada's positions. I was 26 years old and a new lawyer. I had just started a job with Justice Canada, where part of my duties would be to act as "Canada's Representative" at IAP hearings. My training had prepared me to hear specific things. Words I had never spoken in public before had been discussed in detail: What is the difference between fondling and masturbation? How can you tell if one 14 year old was assaulting another or if it was "sexual exploration"? Is anal rape "repeated and persistent" if it occurred four times in one day or must it have happened over a period of months? Is it "intercourse" if the claimant was too

1 Former Governor General of Canada, Truth and Reconciliation Commission of Canada Honorary Witness, quoted in Truth and Reconciliation Commission of Canada, British Columbia National Event Program (18-21 September 2013) at 37.

2 "Indian Residential Schools Settlement Agreement" (8 May 2006), online: <www.residentialschool settlement.ca> [IRSSA]. 
young to ejaculate, or just “masturbation"? Uncomfortable, but desensitized, and somewhat prepared, I could steel myself for the descriptions of abuse. I told myself that this is why I am here. To listen. To bear witness.

I was not prepared to hear, at the end of that first hearing, the closing words my colleague gave as Canada's Representative. I knew that we were to give an "acknowledgment" to the claimant, but I did not understand, until I heard one given, the effect that hearing, and eventually saying, those words would have on me. That day the acknowledgment was long, personal, and for me, unsettling. I realized that my role was to represent my country in a larger way than a lawyer normally represents a client. How to speak within the boundaries of what a legal representative should say and also speak as a citizen and a believer in the idea of Canada, while in full knowledge of the violations of human dignity that my country allowed to happen to the person sitting in front of me was a task I had not contemplated. The emotion of that moment, and of many moments afterwards, was unsettling. I am unsettled. ${ }^{3}$ That is why I am here.

What was this IAP I threw myself into? The IAP is an alternative dispute resolution process that provides monetary compensation to former students who suffered sexual and severe physical abuse while resident at an Indian Residential School (IRS). The "Acts" that may be compensated in the IAP are specific incidents of sexual and severe physical abuse listed in Schedule D of the IRSSA. ${ }^{4}$ The "Consequential Harms" that can be compensated in the IAP, likewise listed in Schedule D, are somewhat broader and include broken bones, nightmares, guilt, pregnancy resulting from assault, psychiatric disorders, post-traumatic stress disorder, difficulties with interpersonal relationships, and sexual dysfunction. ${ }^{5}$ But the consequences that resonated most and that, to me, seemed to be the most pressing to many claimants, was the loss of childhood, of language, of family ties, and of traditional knowledge. ${ }^{6}$ These items were not always directly linked to the "Acts" suffered and were therefore not compensable in the IAP.

To be clear, I did not experience this discordance at every hearing I attended and I do not wish to attribute these concerns to every claimant. Nonetheless it is the element that stayed with me well after the hearings ended. If the claimant's suffering was because of a harm that was not being recognized by the IAP, what use was the process? Was compensation for the sexual abuse also enough to remedy the underlying racism that led to the policy that put the claimant in a position where they were vulnerable to sexual abuse? ${ }^{7}$ Why is it that harms resulting from abuse are compensable but harms resulting from the racism that drove the IRS policy are not? Why did the settlement provide monetary compensation for sexual abuse when the harm I heard most clearly was not the abuse but the loss of family, of language, of

3 For a personal account of experience doing similar work putting "a human face on colonial violence" see Paulette Regan, Unsettling the Settler Within: Indian Residential School, Truth Telling, and Reconciliation in Canada (Vancouver: UBC Press, 2010) at 13.

IRSSA, supra note 2.

Ibid.

See generally Zoe Oxaal, "'Removing That Which was Indian From the Plaintiff”: Tort Recovery for Loss of Culture and Language in Residential Schools Litigation" (2005) 68:2 Sask L Rev 367.

Oxaal, ibid at 373 discusses whether aggravated damages for sexual assault can fill this need but notes that this argument has been rejected to date. 
connection to one's history ${ }^{8}$ Why should I care about that omission when all the parties negotiated and agreed to the IAP as it is?

The beginning of an answer might be found by examining the disconnect I felt between the legal and emotional purposes of the IAP. The empathy I felt with many claimants emanated from what were then recent, and still extremely raw, losses in my own life. A second piece of that answer may be the fact that I began working in the IAP in isolation from the other parts of the IRSSA. ${ }^{9}$ I looked at the IAP as the only remedy, removed from the big picture of truth-finding and reparations. Whatever the answer, the effect was that while I slowly became comfortable with the technical elements of the IAP and my role as Canada's Representative, I could not shake a discomfort about the process as a whole.

During IAP hearings I wore the mantle of Canada's Representative proudly, knowing that I could, or at least that I was trying to, work as a team with the adjudicator and claimant's counsel to create a safe space for the claimant and to demonstrate through my demeanour and words, respect for the people in the room and the process we were undertaking together. I could justify any flaws in the IAP by "doing good" in that moment, for that individual.

But, I constantly felt a need to justify my commitment to IAP work to colleagues who were not involved in IAP hearings, or were not affected by them in the same way I was. I actively avoided the subject with everyone else. It was just too much to explain, too hard to get people to understand. It was daunting; and it bred resentment.

I did not want to speak unless I knew that I could convince every person in my life that what I was doing was important and that it was important to them. This was the crux of my reaction to the many people who passed through my life, whether family, friends, coworkers, classmates, teammates, or strangers. They were not interested in these issues that I knew affected them, and I started to see everyone around me as irresponsible citizens.

I decided that this was not the best topic for a first date.

So I stepped away from my job and embarked on a search for answers. The master's thesis that followed, the basis for this article, began as a journaling of what I wanted to express and why - of my personal experience and its lasting effects on me - a form of autoethnography ${ }^{10}$ that sought to place myself — both as a government lawyer and as a proud Canadian - within the legacy of the IRS policy and, crucially, within its resolution.

The contingencies of human experience I explore operate in a Canada that included (at least) French, English, and Indigenous languages, (at least) Catholic, Anglican, Protestant,

A similar discussion in the context of reparations for loss of traditional territories compared with the loss of Indigenous institutions through colonialism is found in Douglas Sanderson, "Redressing the Rights Wrong: The Argument from Corrective Justice" (2012) 62:1 UTLJ 93.

IRSSA, supra note 2.

10 For examples and discussion of auto-ethnography as methodology, see Carolyn Ellis \& Arthur P Bochner, "Autoethnography, Personal Narrative, Reflexivity: Researcher as Subject" in Norman K Denzin \& Yvonna S Lincoln, eds, Collecting and Interpreting Qualitative Materials, 3rd ed (Thousand Oaks, Cal: Sage Publications, 2008) 199; Tessa Muncey, Creating Autoethnographies (London: Sage Publications, 2010); Heewon Chang, Autoethnography as Method (Walnut Creek, Cal: Left Coast Press, 2008). 
and Indigenous religions, and a variety of economies. The IRS system existed, and the responses to its legacy now exist, in the continuation of that cross-cultural context. This is what Janna Thompson defines as a polity: "a political society that persists through time and across generations: an organized entity capable of acting as an agent and taking responsibility for its actions." 11 Put another way, Canada as a political society is a partnership between those who are living, those who are dead, and those who are yet to be born. ${ }^{12}$

\section{I developed out of a tradition too. In poetic terms:}

I am someone's son or daughter, someone else's cousin or uncle ... I belong to this clan, that tribe, this nation. Hence what is good for me has to be good for one who inhabits these roles. As such I inherit from the past of my family, my city, my tribe, my nation, a variety of debts, inheritances, rightful expectations and obligations. These constitute the given of my life, my moral starting point. ${ }^{13}$

Because I cherish my joint Anglo-French heritage, I honour my forebears by speaking their languages and maintaining many of their traditions, though some traditions, regular Sunday mass, for example, have fallen away over the years. ${ }^{14}$ I have reaped the benefits of existing in a bilingual and multicultural space that was created for me by generations of genealogical and political ancestors. "Canada" as a polity allows me to unite my Anglo- and FrancoOntarian halves into a single unit, "Canadian," when I might otherwise be required to divide my loyalties. I locate myself not so much in the "present" but at a point on the continuum my ancestors started and that will continue after I am dead. In this simple, personal way, I have accepted a responsibility to my two cultures. I also accept, both as a practical reality of modern life, and as a choice I have made, to tie myself to the Canadian polity that, on a larger scale, made commitments to my forebears and to $\mathrm{me}^{15}$ from which I benefit and intend to defend and carry forward for subsequent generations of Canadians whether they are my direct descendants or members of the polity generally. My identity is tied to my membership in Canadian society. My personal narrative is therefore tied to the intergenerational narrative of my country. ${ }^{16}$ Following this concept, as a corollary of the benefits I have received, if my polity has failed to uphold a commitment, or has caused a harm, I live with the consequences. The fact that I played no part in the harmful act is irrelevant, ${ }^{17}$ just as I played no role in the good Canada and Canadians had done before I appeared. This is why I feel responsible for the IRS legacy. I just couldn't, in that first IAP hearing, put that feeling into words.

Janna Thompson, Intergenerational Justice: Rights and Responsibilities in an Intergenerational Polity (New York: Routledge, 2009) at 1 [Thompson, Intergenerational Justice].

12 Janna Thompson, Taking Responsibility for the Past: Reparation and Historical Justice (Cambridge: Polity Press, 2002) at 148, citing Edmund Burke, Reflections on the Revolution in France (November 1790) [Thompson, Taking Responsibility].

13 Alasdair MacIntyre, After Virtue: A Study in Moral Theory, 2nd ed (London: Duckworth, 1981), cited in Thompson, Taking Responsibility, ibid at 11.

14 Thompson, Intergenerational Justice, supra note 11 at 67 . We have a duty to be true to their memories and intentions but are able to make our own decisions based on better reasoning, or at least our own updated reasoning. For example, I do not attend church, as both my grandmothers did.

15 See for example, section 23 (language rights), and section 15 (equality rights for women) enshrined in the Canadian Charter of Rights and Freedoms, Part I of the Constitution Act, 1982, being Schedule B to the Canada Act 1982 (UK), 1982, c 11.

16 Thompson, Taking Responsibility, supra note 12 at 11 [citations omitted].

17 Thompson, Intergenerational Justice, supra note 11 at 79-80. 
What I felt was a dual responsibility. The first, selfishly, was a growing sense that my antecedents, in their stewardship of the Canadian polity, had not upheld their obligation to me: that I had been thrown into those hearing rooms and was experiencing so much confusion because of decisions that should have been decided differently. I was angry not on behalf of the abused claimant, but for myself. The respectful intergenerational relationship the claimant and I were meant to have had was damaged.

The second was expected: that my polity had breached its obligations to the polity of the claimant. As stated by Douglas Sanderson, there was "no wrong in the mere arrival of settler people ... the wrong was the failure of settler governments to create a just political association" with their Indigenous hosts. ${ }^{18}$ Instead, the treaty that included a school for children on the reserve was transformed into a statutory requirement to be taken to a boarding school where harm was done to the intergenerational interests of the survivor. ${ }^{19}$ Children across the country were not treated with the dignity and respect due to them as human beings. I recognize this, but I struggle with taking the blame for those acts. I am not liable for the IRS policy. I resist any shame or guilt. I don't believe I deserve it. I didn't create, carry out, or want the IRS policy. I needed a different language, a different framework, for thinking about my role, both personally and professionally, about the IRS policy.

The conceptual solution was provided by Thompson's work on intergenerational responsibilities, discussed above, and Iris Marion Young's concept of a public and shared concept of responsibility for structural injustice. ${ }^{20}$ Both concepts engage members of a society who are not personally to blame for the cause of harm in the resolution of those harms. This article develops this work in a Canadian context.

I have had misgivings about my research: that I might be trampling on the lives, experiences, and stories of others - that I had no right to tell the story of the residential schools because I am not Indigenous and have never experienced abuse. But as John Milloy has written, this is not an Indigenous story. ${ }^{21}$ The history of the IRS system is a Canadian story that can, and should, be explored by all Canadians:

The system is not someone else's history, nor is it just a footnote or a paragraph, a preface or chapter, in Canadian history. It is our history, our shaping of the "New World"; it is our swallowing of the land and its First Nations peoples and spitting them out as cities and farms and hydroelectric projects and as strangers in their own land and communities. ${ }^{22}$

Sanderson, supra note 8 at 103 .

Thompson, Intergenerational Justice, supra note 11 at 81.

Iris Marion Young \& Martha Nussbaum, Responsibility for Justice (Oxford: Oxford University Press, 2011) at 78.

21 John S Milloy, A National Crime: The Canadian Government and the Residential School System, 1879 to 1986 (Winnipeg: University of Manitoba Press, 1999).

Ibid at $\mathrm{xxx}$ [emphasis in original]. 
Milloy is joined by the Commissioners of the Truth and Reconciliation Commission of Canada who also wrote about the IRS legacy as a joint story of which all Canadians are a part:

It is painful to discover that, as a nation, we have not always lived up to our ideals or the image we seek to project on the international stage. That does not mean we should abandon our ideals. We cannot change the past, but the future is in our hands. We are called to undertake the ongoing work of reconciliation: to right the relationship between Aboriginal and non-Aboriginal Canada. This is no easy or straightforward task. We need to revive old visions in which these communities came together in a spirit of sharing and mutual exchange. $^{23}$

In this understanding I ground my research and join in this process of witnessing and sharing.

In keeping with the understanding that the IRS legacy is a Canadian story, I have an intensely personal goal for this project: to weave together the strands of my duties acting as Canada's Representative, my identity as a Canadian, and my relationships with the people I meet in daily life. While examined through the prism of the law, the IRS legacy is inherently social and political. It involves a range of actors in Canadian society in the past and the present.

I come to the conclusion that we, as Canadians, need to understand our institutions better in order to address harm. To do this I suggest a new paradigm — intergenerational responsibility — to guide our application of existing alternative dispute resolution mechanisms. To illustrate: when we apply the criminal justice system to certain events, we limit ourselves to the paradigm of the criminal law - the harms it recognizes and the parties it seeks to punish or compensate. If the system was not built to address a particular harm, that harm simply does not exist. This is, in short, backwards. If we focus instead on the harms caused and on recognizing them as having been caused by actors within our polity, we are free to address the causes of harm and appropriate reparations free of institutional constraints. In particular, we must look anew at how we determine, assign, and accept responsibility for harm.

\section{HISTORY AND HARMS}

The Indian Residential Schools policy caused harm. "Harms" can be described in many ways: individual, cultural, tortious, criminal, personal, property-based, historical, continuing, intergenerational, intentional, or unintentional, to name a few options. These descriptions are also classifications that have repercussions for the legal and political recognition of harm. For example, only certain harms are recognized by the current Canadian justice system. 
The extensive report of the Truth and Reconciliation Committee (TRC) details the racist origins of the IRS policy, ${ }^{24}$ the educational and health failures of the schools, ${ }^{25}$ and the emotional, physical, and sexual abuses suffered by generations of students. Bookstore shelves are now lined with titles by survivors and Indigenous authors who write heartbreaking and heartwarming stories of their lives before, during, and after Residential Schools, and on the intergenerational effects on their communities. ${ }^{26}$ I will not repeat those stories here other than to cite them as the source of the list of harms I attempt to place within the Canadian justice and political systems. In particular, it is important to this analysis to recognize that the IRS policy caused intended and unintended harms. The sexual and severe physical abuse of students that have made headlines through litigation and novels was unintended. The intended harms are less widely recognized, but these are the origins of the IRS policy: the removal of Indigenous languages and cultures from Indigenous children. In the words of the TRC: cultural genocide. ${ }^{27}$ Not coincidentally, these are the harms that are foreign to Canadian law.

In order to analyze the harms I regroup them into six loose categories recognizing that in the lived experience of survivors these categories might overlap. Later I will use these categories to demonstrate whether our Canadian legal and political institutions are able, or not, to address the full range of harms stemming from the IRS policy. They are as follows:

(1) Sexual Abuse: Sexual abuse is perhaps the most obvious harm stemming from the IRS policy. While not every student was abused, nearly half of the estimated 80,000 living survivors made a claim in the IAP. ${ }^{28}$

(2) Physical Abuse: Similarly well-known is the physical abuse that occurred, though it took several forms. Bruising and broken bones suffered as a result of either beatings or unsupervised play are among the claims made in the IAP and were not uncommon. Corporal punishment is a more controversial claim considering its use in schools was common through the $1970 \mathrm{~s}^{29}$ and that corporal punishment of children by parents has been allowed by the SCC. ${ }^{30}$ Also included in this category could be overwork in industrial schools.

Truth and Reconciliation Commission of Canada, Canada's Residential Schools: The History, Part 1 Origins to 1939 (Montreal \& Kingston: McGill-Queens University Press, 2015) at 21 (goals of colonial education systems broadly), 153 (development of the IRS policy) [TRC, Final Report Part 1]. See Report of the Royal Commission on Aboriginal Peoples: Looking Forward, Looking Back, vol 1 (Ottawa: Supply and Services Canada, 1996) at 356 [RRCAP, vol 1] (1907 Bryce Report on sanitation at the schools).

26 See e.g. Alice Blondin-Perrin, My Heart Shook Like a Drum: What I Learned at the Indian Mission Schools, Northwest Territories (Ottawa: Borealis Press, 2009); Theodore Fontaine, Broken Circle: The Dark Legacy of Indian Residential Schools, A Memoire (Victoria: Heritage House, 2010); Elizabeth Furniss, Victims of Benevolence: The Dark Legacy of the Williams Lake Residential School (Vancouver: Arsenal Pulp Press, 1995); Celia Haig-Brown, Resistance and Renewal: Surviving the Indian Residential School (Vancouver: Arsenal Pulp Press, 1988).

$27 \quad$ TRC, Final Report Part 1, supra note 24 at 3.

28 Indian Residential Schools Adjudication Secretariat, "Adjudication Secretariat Statistics: From September 19, 2007 to December 31, 2017," online: <www.iap-pei.ca/stats-eng.php>.

29 Paul Axelrod, "Banning the Strap: The End of Corporal Punishment in Canadian Schools" (6 January 2011), online: The Canadian Education Association <https://www.edcan.ca/articles/banning-the-strapthe-end-of-corporal-punishment-in-canadian-schools $/>$. 
(3) Inadequate Care: As documented in the Bryce Report, ${ }^{31}$ many IRSs provided inadequate care, nutrition, and sanitation. Recent research has also revealed that nutritional experiments were carried out at residential schools. ${ }^{32}$

(4) Emotional Abuse: Many survivors suffered emotional harm from the sudden change in discipline and as a result of the racism of many teachers and supervisors.

(5) Cultural Harm: Included in this category are the prohibition of the use of native languages, and the confiscation of traditional clothing and food. Students were not allowed to practice their religions or any cultural traditions. Because students were separated from family for long periods of time, many lost the ability to speak their languages and also lost, or were not initiated into, their religious or cultural practices. The separation from family also resulted in feelings of abandonment and general weakening of family ties. Survivors did not receive training in how to be children or siblings, or how to be parents. "Cultural harm" is meant to capture noncorporeal damage such as loss of language, loss of family ties, inability to maintain traditions and culture, and the secondary effects of those losses such as a lack of parenting skills, lack of social and support structure, confusion as to identity, and a lack of knowledge of the surrounding world required to survive in either Indigenous or non-Indigenous settings.

(6) Inadequate Education: Finally, many students did not receive an education adequate to prepare them for life in the Canadian economy and were simultaneously deprived of the education that would have been provided by their communities. The result was often unemployment or underemployment.

As stated above, these categories are loose and fluid. Individual acts might be placed in several categories simultaneously, for example, where sexual abuse is accompanied by or facilitated by emotional abuse or racist language, and is kept hidden through bribes of fresh fruit or candy to a starving student.

The story of the Residential Schools is not a history I learned in school. By meeting survivors in IAP hearings while acting as Canada's Representative, I met my history, face-toface, and wasn't sure what to think about it. I now understand that learning "history changes who we were, not just who we are," 33 and that reckoning is not easy. The Law Commission of Canada (LCC), in its report on institutional child abuse in Canada noted that

[a]s a society, we cannot simply accept without question and comment the choices made in the past, and leave it to those who suffered to get on with their lives as best they can. We must confront the consequences of

See RRCAP, vol 1, supra note 25 at 356.

Ian Mosby, "Administering Colonial Science: Nutrition Research and Human Biomedical Experimentation in Aboriginal Communities and Residential Schools, 1942-1952" (2013) 46:91 Histoire Sociale/Social History 161.

33 Elazar Barkan, The Guilt of Nations: Restitution and Negotiating Historical Injustices (New York: Norton, 2000) at x [Barkan, Guilt]. 
those choices and do what is necessary to rectify the wrongs that were done to innocent children - our children. $^{34}$

We made choices, as a country, and those choices had consequences. The measure of our country, today, is, I hope, how we deal with our mistakes.

Armed with the knowledge of the intended and unintended consequences of the IRS policy and of the broad categories of harm set out above, I now detail the theories behind the institutions used in Canadian law and society to address harm generally.

\section{LEGAL THEORY}

This discussion is divided into two sections. The first section analyses the established euro-Canadian criminal and civil law mechanisms along with common alternative mechanisms. These mechanisms are premised upon certain assumptions about harms and responsibility of wrongdoers that prevent them from adequately theorizing and responding to the harms of the IRS policy. The second section considers the application of "transitional justice" mechanisms to the IRS legacy. Transitional justice broadly theorizes and connects several juridical and non-juridical mechanisms that are used to address large-scale human rights abuses..$^{35}$ Transitional justice mechanisms are both flexible and context-specific, making their importation to Canada interesting but problematic.

\section{A. InSTITUTIONAL RELIANCE}

Unfortunately, child abuse has occurred at many types of institutions across Canada. In March 2000, on request of the Minister of Justice, ${ }^{36}$ the Law Commission of Canada (LCC) published an "inventory and comparative assessment of approaches available" ${ }^{" 37}$ to address institutional child abuse. The LCC was asked to identify "[w] hat types of processes would best address wrongdoing, while affording appropriate remedies, and promoting reconciliation, fairness and healing. ${ }^{" 38}$ The LCC looked at three categories of abuse: physical, sexual, and "other" types (a category that included emotional, psychological, spiritual, racial, and cultural abuse). Physical and sexual abuse were at the centre of the Minister's reference "because these are the categories of abuse which are unquestionably a basis for legal liability, whether civil or criminal." ${ }^{39}$ The "other" types of abuse, according to the LCC, "are less clearly compensable in legal proceedings, particularly if they are not tied to instances of either physical or sexual abuse. ${ }^{\$ 4}$

The LCC examined several mechanisms, including the criminal justice process, civil actions, criminal injuries compensation programs, ex gratia payments, Ombudsperson

Law Commission of Canada, Restoring Dignity: Responding to Child Abuse in Canadian Institutions (Ottawa: Law Commission of Canada, 2000) at 3 [LCC, Report].

"What is Transitional Justice?" online: International Center for Transitional Justice <www.ictj.org/ about/transitional-justice>.

Law Commission of Canada Act, SC 1996, c 9, s 5(1)(b).

LCC, Report, supra note 34 at 426, Appendix A.

Ibid at 2.

Ibid at 41

Ibid. 
Offices, children's advocates and commissions, public inquiries, truth commissions, community initiatives, and redress programs. The LCC's work was thorough and informative and I rely on it, with some necessary updates, to draw out the constituent elements of Canadian criminal, civil, and alternative dispute resolution (ADR) mechanisms and discuss their benefits and limitations when applied to the IRS policy. Specifically, I will draw out the concept of harm that triggers each mechanism and the concept of responsibility that animates it.

\section{CRIMINAL LAW}

The criminal law is the pre-eminent mechanism for dealing with serious harms like assault. It is " $[\mathrm{t}]$ he body of law defining offenses against the community at large, regulating how suspects are investigated, charged, and tried, and establishing punishments for convicted offenders. ${ }^{41}$ Now found entirely in statute, the criminal law initially developed through judges' views of what acts caused harm to society and were morally reprehensible based, at least in part, on ecclesiastical offences. ${ }^{42}$ While the criminal law is now secularized, it remains steeped in the concepts of "moral blameworthiness and social harm." ${ }^{\text {"43 }}$ The criminal law today is concerned with those acts that society has deemed to be so dangerous that their commission warrants the intervention of the state to define, punish, and prevent.

The LCC succinctly summarized the history and purpose of the criminal law:

\footnotetext{
The primary goal of the Canadian criminal justice system is to provide a public forum for the recognition and punishment of wrongful conduct defined by Parliament as a crime. Its processes are designed to ensure a fair trial, to minimise the chances of an unjust conviction, and to impose an appropriate punishment upon individuals who have been convicted.
}

Historically, the criminal justice system was developed to forestall blood feuds and private retribution. Today, the criminal law is also viewed as a statement of society's core values. The State takes on the role of prosecutor and is responsible for proving that the accused has committed a crime. ${ }^{44}$

Within these definitions are two key assumptions: (1) that there is an objective, societally agreed-upon definition of crime (harm) ${ }^{45}$ and (2) that there is an individual, identified perpetrator, who is directly responsible for the harm. This structure has specific consequences for the capacity of the criminal law to respond to the IRS legacy.

\section{a. Defining Crime}

The criminal law is a mechanism to enforce societal values, and to recognize and punish wrongful conduct as defined by parliamentarians. In defining "crime," Parliament indicates the limits of acceptable behaviour and pledges itself to enforce those standards through the prosecution of offenders. There is a long-standing debate in legal theory about the proper

Black's Law Dictionary, 8th ed, sub verbo "criminal law."

Morris Manning \& Peter Sankoff, Criminal Law, 4th ed (Markham, Ont: LexisNexis, 2009) at 23.

Ibid.

LCC, Report, supra note 34 at 115.

Manning \& Sankoff, supra note 42 at 24-25. 
foundation of the criminal law with some concept of "harm" being applied. ${ }^{46}$ The Supreme Court of Canada recognized in $R$. v. Butler that " $[\mathrm{t}]$ o ground criminal responsibility, the harm must be one which society formally recognizes as incompatible with its proper functioning., ${ }^{, 47}$ In 2005 the Supreme Court held that whatever the standard, it must be objective: "[t]he requirement of formal societal recognition makes the test objective. The inquiry is not based on individual notions of harm, nor on the teachings of a particular ideology, but on what society, through its fundamental laws, has recognized as essential." ${ }^{\text {48 }}$ While always "objective," the definition of specific crimes will shift with changes in society.

The criminal law has a particular place in society as the forum in which behaviour is regulated, on the basis of harms caused to others, that are "objectively" found to be contrary to foundational societal values. This regulation occurs in full view of the public, with the intent to enforce standards and create a public record. Its purposes are "to adjudicate individual responsibility and to establish the truth about an event in controversy." 49

A consequence of the public nature of the criminal act is that a crime is a public wrong. ${ }^{50}$ The inference is that this harm warrants attention by the broader community in contrast to a civil proceeding where only private individuals are involved. The harm is understood as being done to the community, not to the individual. ${ }^{51}$ Because of this greater importance, the state takes over the prosecution and victims are termed "complainants": witnesses who might provide evidence in the case against the accused but who are not themselves parties to the process. ${ }^{52}$

The public re-enforcement of social norms can provide a great benefit to victims of crime by meting out punishment to wrongdoers and by validating the victim's position in society, thereby restoring him or her to a position of dignity. According to one study published in 2005 , victims of sexual abuse sought this validation and restoration from the criminal process:

\footnotetext{
Beyond acknowledgment, what survivors sought most frequently was vindication. They wanted their communities to take a clear and unequivocal stand in condemnation of the offense. Community denunciation of the crime was of great importance to the survivors because it affirmed the solidarity of the community with the victim and transferred the burden of disgrace from victim to offender. The survivors were keenly aware that the crimes were intended to dishonor and isolate them; they sought, therefore, the restoration of their own honor and the reestablishment of their own connections with the community. ${ }^{53}$
}

The public nature of the criminal law, and third-party adjudication, provides this relief.

For a discussion of this debate, see $R v$ Malmo-Levine; $R v$ Caine, 2003 SCC 74.

[1992] 1 SCR 452 at 485.

$R v$ Labaye, $2005 \mathrm{SCC} 80$ at para 33 [Labaye].

Ruti G Teitel, Transitional Justice (New York: Oxford University Press, 2000) at 72.

Manning \& Sankoff, supra note 42 at 27.

Ibid at 29.

Ibid at 28.

Judith Lewis Herman, “Justice from the Victim’s Perspective” (2005) 11:5 Violence Against Women 571 at 585 . 
Some of the harms of the IRS policy, specifically the severe physical and sexual abuse suffered by survivors, are recognized in the Criminal Code $e^{54}$ as the offences of Assault ${ }^{55}$ and Sexual Assault ${ }^{56}$ respectively. ${ }^{57}$ However, there are no criminal offences that capture other harms, such as emotional abuse, cultural loss, or loss of educational opportunity. For example, a survivor would find no relief or denunciation available under the Criminal Code ${ }^{58}$ for the great loneliness endured in the IRS, nor is it a criminal offence for school administrators to refer to students by a number.

\section{b. The Existence of a Criminal}

A second important goal of defining crime is to provide clarity in the law for offenders. ${ }^{59}$ The criminal, not the victim, is the epicentre of the criminal process. It is they who have contravened society's norms and are responsible for the harm caused. The goal of any criminal code is to create a standard of conduct and to ensure that punishment does not befall any person who did not intentionally breach the law.

As such, criminal procedure is as much about protecting the rights of the accused and ensuring against wrongful conviction as it is about addressing harm. As the Supreme Court stated:

The requirement of formal endorsement ensures that people will not be convicted and imprisoned for transgressing the rules and beliefs of particular individuals or groups. To incur the ultimate criminal sanction, they must have violated values which Canadian society as a whole has formally endorsed. ${ }^{60}$

As the LCC stated "the criminal justice process is well-suited to identifying individual perpetrators and holding them liable. It is less well-suited to uncovering any systemic problems that may have allowed the abuse to occur or to continue for a lengthy period." $" 61$ When applied to the IRS legacy, the criminal law can only punish individual perpetrators of abuse. It cannot address government policies.

\section{c. Criminal Misgivings}

This focus on the perpetrator causes some difficulty in applying the criminal law to the harms of the IRS policy. The police lay charges and prosecutors prosecute offenders as a public duty. They are responsible to society at large. They are not the victim's advocates. ${ }^{62}$

Criminal Code, RSC 1985, c C-46.

Ibid, ss 265-68.

Ibid, ss $150-62,271-73$, especially ss $151-59$.

Note that crimes are defined in and by the times creating some anachronisms in terminology. For example, male-on-male rape was not included in the definition of "rape" in the Criminal Code, supra note 54 until 1983, so male-on-male rape that occurred prior to 1983 but prosecuted afterwards must be done under other sections or terms, notably "buggery," which was removed from the Criminal Code in the 1970 s as homosexuality became widely accepted in Canadian society: LCC, Report, supra note 34 at 116.

Criminal Code, ibid.

Don Stuart, Canadian Criminal Law: A Treatise, 6th ed (Scarborough: Carswell, 2011) at 128.

Labaye, supra note 48 at para 35.

LCC, Report, supra note 34 at 122.

Ibid at 115,117 . In fact, the criminal law system is facing increased criticism for its treatment of victims, particularly as witnesses. See e.g. Elaine Craig, "The Inhospitable Court” (2016) 66:2 UTLJ 197. 
Prosecutors are afforded the discretion to prosecute an offender for a particular offence based on their assessment of the public interest in pursuing the prosecution. ${ }^{63}$ That said, one of the purposes of punishment is to restore order and trust between the state and its citizens.

Other procedural aspects, like the need for evidence, pose barriers to the criminal law being an effective response to harm stemming from the IRS policy. For example, in cases of historical abuse like those that occurred at an IRS, evidence may have been lost or destroyed, and witnesses may have died or may be in advanced stages of memory loss, making their evidence unreliable in court. ${ }^{64}$ The need to cross-examine victims may also be a barrier, as they may not be willing to submit to the vigorous ${ }^{65}$ and potentially re-traumatizing crossexamination by the accused's counsel. Finally, the criminal law cannot be engaged when the accused has died or cannot be identified, making it unavailable in many cases of historical abuse.

The criminal law is an important tool. By setting standards of behaviour through the law and then enforcing those standards, society guides its members towards acceptable behaviour. When laws are broken it supports and vindicates the victim by publicly identifying and denouncing the perpetrator and meting out punishment, thereby deterring further harmful behaviour. In the IRS context, the criminal law is a useful tool for recognizing and prosecuting specific acts of physical and sexual abuse by wrongdoers at an IRS.

That said, the criminal law has several in-built assumptions: that there is an individual, identified perpetrator who is solely responsible for the act, and that only the specific harms that are clearly accepted by society and written in statute are punishable. These assumptions prevent the criminal law from addressing the full range of harms caused by the IRS policy.

\section{TORT LAW}

The second standard mechanism for the recognition of harm in Canadian society is the civil justice system. The civil law broadly, is any matter that is not criminal in nature including contract, fiduciary duties, ${ }^{66}$ statutory duties,${ }^{67}$ and, most relevant to this study, the "civil wrong" known in the common law provinces as "torts," and as "civil liability" in the

Krieger $v$ Law Society of Alberta, 2002 SCC 65 at paras 46-47. See also $R v$ Anderson, 2014 SCC 41 at paras $39-45$.

LCC, Report, supra note 34 at 119.

Ibid at 120 .

Claims of fiduciary duties have been made against the Crown in the IRS context, notably in Blackwater $v$ Plint, 2005 SCC 58 at para 56 [Blackwater], but to date the courts have not found a fiduciary duty to students in residential schools (Indian or otherwise) generally, unless the children were wards of the government: see Reference re Broome v Prince Edward Island, 2010 SCC 11 at paras 66-67. But see Canada (Attorney General) v Anderson, 2011 NLCA 82 at para 63 where the Newfoundland and Labrador Court of Appeal did not close the door to a fiduciary duty claim at the certification stage of a class action. For a discussion of fiduciary duties owed by government to children in care, see $K L B V$ British Columbia, 2003 SCC 51 at para 38. 
Quebec civil law tradition. ${ }^{68}$ Again, the LCC accurately and succinctly described the basic principles of tort law:

\begin{abstract}
The basic premise of a civil action is that people are responsible for the injuries they cause to others. Under both the common law and the civil law of Quebec, a plaintiff must prove three basic elements in order to succeed: the fault of the defendant, the injury to the victim, and a causal connection between the fault and the injury. Physical, psychological or sexual violence constitutes a civil wrong.
\end{abstract}

Quebec civil law does not distinguish between different categories of wrongful conduct. The principles of liability are the same regardless of the type of fault alleged. ${ }^{69}$

The tort process is a victim ${ }^{70}$ driven and financed process. The victim has more control over the process than in the criminal law but also bears the burden (and cost) of proving claims.

Like the criminal law, tort law makes assumptions about harm and the responsibility of wrongdoers that prevent it from addressing the full IRS legacy. Standards of behaviour are defined, but the end goal in this instance is assumed to be compensation of the victim in a cold transaction of either goods or money.

\title{
a. The Wrongs of Tort ${ }^{71}$
}

Like the criminal law, tort law is based upon a societal consensus of appropriate behaviour of individuals towards one another. While this consensus is arrived at by Parliament in the case of the criminal law, in tort law, it is arrived at through the process of following and building upon juridical precedent (stare decisis) as society has evolved. This process is slow but does allow the law to evolve to tackle the problems of modern life. ${ }^{72}$ In the civilian tradition, civil liability is found in article 1457 of the Civil Code of Quebec ${ }^{73}$ and has been elaborated through judicial decisions.

Some modes of litigation, like class actions procedures, can be tools to encourage a settlement $^{74}$ (by sheer force of numbers), and in the course of negotiating a settlement the parties might be able to take into account harms that do not strictly fall within the tort-law paradigm and judge-ordered remedies. ${ }^{75}$

Torts that might apply to the harms caused by the IRS policy are assault and battery, in the case of physical and sexual abuse, intentional infliction of emotional suffering, in the

For the purposes of this article, I will use the term "tort law" to describe both the civil and common law concepts as the majority of IRS lawsuits in Canada are framed in the common law jurisdictions as torts. LCC, Report, supra note 34 at 145-46 [citations omitted].

Ibid at 147 and footnotes (applies to directs victims of the IRS policy, but tort actions may lie for indirect victims like family members in certain situations).

A cheeky title I borrow from Joanne Conaghan \& Wade Mansell, The Wrongs of Tort, 2nd ed (London: Pluto Press, 1999).

A prominent example is the shift that occurred in Donoghue v Stevenson, [1932] UKHL 100 [Donoghue] where liability was extended to third-party manufacturers for defects in their products that affect the end consumer who otherwise has no relationship to the manufacturer.

Civil Code of Quebec, LRQ, c C-1991.

Emily Unrau, "Using Class Actions to Redress Historical Wrongs Committed by the Government" (2013) 8:2 Can Class Action Rev 339 at 362.

Ibid at 355 . 
case of many of the emotional harms, and negligence, in the cases of inadequate nutrition and care.

\section{b. A Duty to Care}

The standard form of liability in tort is the direct fault of a wrongdoer. In order to succeed in court, plaintiffs must prove that they suffered damage; that the damage was caused by the actions of a defendant who was in a relationship of proximity to the plaintiffs such that it was reasonably foreseeable that those actions would cause harm (a duty of care) ${ }^{76}$ and that the standard of care was breached. Finally there must be no policy reasons why liability should not accrue such as remoteness of damage. ${ }^{77} \mathrm{~A}$ further analysis is required when considering liability of a government entity, as the Crown is immune from liability for policy decisions. ${ }^{78}$ The categories of relationships are not closed and do evolve. ${ }^{79}$ For example, civil courts now recognize indirect liability, like the vicarious liability of employers for the tortious acts of their employees under specific conditions. Those conditions are that the nature of the employee's job created or enhanced a risk that abuse would occur. ${ }^{80}$ Vicarious liability is also recognized in article 1463 of the Civil Code of Quebec. ${ }^{81}$ Instead of proving "fault," vicarious liability under article 1463 requires proof the wrongdoing occurred "in performance of his/her duties." 82 Through these tools plaintiffs are able to draw governments and institutional actors into lawsuits where it would not have been possible before, or in the criminal law process.

A second evolution of traditional litigation is the class action. While class actions have the same requirements as other actions in the standards and burdens of proof, causation, and fault, they allow plaintiffs to combine their financial resources and act as one against a defendant. ${ }^{83}$ The claimants must form a "class" and be certified by the court using the criteria set out in the relevant class action legislation. ${ }^{84}$ Briefly, the claimants must prove that they have a cause of action, that there are two or more members of the class that have common issues, that the class action is the preferable procedure for resolving the claim, and that there is a class representative who has a plan for advancing the case.$^{85}$ By having a representative act for the class many survivors are spared the burden of testifying and the claims are resolved simultaneously instead of one by one, speeding up the process considerably. ${ }^{86}$

Jennifer Llewellyn has analyzed the ability of the tort law system to respond to IRS abuse. Among the advantages she points out are the legitimacy and authority of a court proceeding,

77

Donoghue, supra note 72, as discussed by the Supreme Court of Canada in Cooper v Hobart, 2001 SCC 79 at paras 22-39 [Cooper].

Kamloops $v$ Neilsen, [1984] 2 SCR 2 at 10.

Oxaal, supra note 6 at 390.

Cooper, supra note 76 at para 23.

Bazley v Curry, [1999] 2 SCR 534 at para 42; Blackwater, supra note 66 at para 20. Supra note 73 .

Ibid.

Western Shopping Centres v Dutton, 2001 SCC 46 [Western Shopping Centres]; Class Proceedings Act, RSBC 1996, c 50 [Class Proceedings Act (BC)].

See e.g. Class Proceedings Act, 1992, SO 1992, c 6, s 5. In jurisdictions that do not have class action legislation the process for "representative actions" is proscribed by the "Dutton Test" set out by the Supreme Court of Canada in Western Shopping Centres, ibid.

Class Proceedings Act (BC), supra note 83, s 4.

For a detailed discussion of the appropriateness of class actions to historical wrongs like the IRS policy, see Unrau, supra note 74. 
including the public recognition of wrongdoing and the perpetrator receiving his or her "desert" in the finding of liability and order of damages ${ }^{87}$ Llewellyn writes that victims receive satisfaction in the sense of vindication and acknowledgement of their rights and the harms done to them in the trial process. ${ }^{88}$ She notes that the court process and rules of civil procedure protect, to some extent, vulnerable parties. ${ }^{89}$ The public nature of the process and judgment allow the wrongdoers and harms to enter into the broader Canadian consciousness. Precedents are established through the decisions leading to a consistent statement from the courts that the abuses occurring in the IRS and, perhaps, the IRS system itself, did not conform to society's values. ${ }^{90}$ Finally, the civil trial process is known and familiar to victims so they can prepare themselves for the stresses of a trial. ${ }^{91}$ The LCC echoed many of these advantages in its Report. ${ }^{92}$

\section{c. Incivility in the Process}

While the civil trial process recognizes a broader range of harms, and of wrongdoers, than the criminal law, Llewellyn and others have also identified many disadvantages of pursuing a civil claim. Chief among them are the high financial cost to individuals and the exorbitant contingency fees charged by some lawyers. ${ }^{93}$ The arduous and protracted process has the potential to re-victimize survivors particularly because, like the criminal law, trials are not geared towards telling their entire story, only those parts required to prove the elements of the cause of action. ${ }^{94}$ Further, the adversarial nature of the process does not account for the complex relationships between survivors and the state, as the civil trial assumes the matter is a private one, ignoring the substantial public element in harms that stem from state policy, ${ }^{95}$ as in the case of the IRS legacy. Tort law also contains a narrow concept of harm that is limited to the substance of previous torts and conceives of plaintiffs and victims as individuals, not as a community or a family. ${ }^{96}$ The assumption of adverse interests hardens the parties in their positions and ignores the fact that they may have significant common goals and interests, limiting the ability of the parties to compromise ${ }^{97}$ Finally, the corrective justice theory on which tort law is based assumes compensation and, to a limited extent, punishment to be the end goals, ignoring other remedies survivors seek like reconciliation and emotional healing, ${ }^{98}$ and narrowing responsibility for the harm to the tortfeasor, letting all others who might have contributed to the circumstances leading to the harm off the hook.

Jennifer Llewellyn, "Dealing with the Legacy of Native Residential School Abuse in Canada: Litigation, ADR, and Restorative Justice" (2002) 52:3 UTLJ 253 at 266 [Llewellyn, "Dealing with the Legacy"]. Ibid at 266. This point was echoed by Elizabeth Adjin-Tettey, "Righting Past Wrongs Through Contextualization: Assessing Claims of Aboriginal Survivors of Historical and Institutional Abuses" (2007) 25:1 Windsor YB Access Just 95 at 110, 116.

Llewellyn, "Dealing with the Legacy," supra note 87 at 266.

Ibid at 267.

Ibid at 268 .

LCC, Report, supra note 34 at 161.

Llewellyn, "Dealing with the Legacy," supra note 87 at 268.

Ibid at 269; LCC, Report, supra note 34 at 161.

Llewellyn, "Dealing with the Legacy," ibid at 270-71.

Ibid at 271. This is a continuing issue in the "60s Scoop" litigation. See e.g. Brown v Canada (Attorney General), 2017 ONSC 251.

Llewellyn, "Dealing with the Legacy," ibid at 271-72.

Ibid at $274-75$. 
There are still more barriers. The difficulties of proof are great: until the IRSSA, ${ }^{99}$ no survivor had proven a civil claim for vicarious liability where the abuser/employee had not already been convicted. ${ }^{100}$ Prescription periods limit the time frame for bringing civil claims. ${ }^{101}$ For example in Yukon ${ }^{102}$ and Ontario, ${ }^{103}$ claims of physical assault must be brought within two years of the event. That said, most jurisdictions in Canada have removed the limitations period for sexual assault at least in cases where the victim was a minor or otherwise under the control of the perpetrator. ${ }^{104}$

The framing of IRS harms in tort is also problematic. The main causes of action against the government have been claims of fiduciary duties, non-delegable statutory duties, and vicarious liability for the negligent operation of the schools. ${ }^{105}$ Survivors' and their descendants' claims for further harms, including "cultural genocide" have not, to date, been recognized as a cause of action. ${ }^{106}$ Some authors have questioned the ability of tort law to address harms that are not individual, or that are not exclusively caused by or experienced by individuals, like loss of language or culture. ${ }^{107}$ Others have argued that cultural loss could be included under current torts, specifically intentional infliction of emotional suffering, ${ }^{108}$ but there has been no successful case to date. ${ }^{109}$

\section{Civil Alternatives}

In part in order to address some of these barriers to dispute resolution, the tort law system has developed "alternative" dispute resolution (ADR) mechanisms that, while based on the principles of corrective justice and more specifically of tort law, operate as modified processes that have benefitted victims of harm, including IRS survivors. ADR has the potential to eliminate some of the financial and time burdens of the current civil litigation process and to allow survivors to resolve their claims in a culturally sensitive manner.

\section{a. Resolving the Issues (or Skirting Them?)}

ADR can be conducted within the framework of a court action or prior to its commencement. ${ }^{110}$ ADR allows disputants to focus on their goals and tailor a process to their needs, though this assumes that settlement is appropriate. ${ }^{111}$ The parties take a flexible approach to resolving the dispute but have not redefined the underlying claim to break free from the tort-law framework. ${ }^{112}$ Simple settlement, Llewellyn notes, may not be appropriate

Supra note 2.

Bruce Feldhusen, "Civil Liability for Sexual Assault in Aboriginal Residential Schools: The Baker Did It" (2007) 22:1 CJLS 61 at 89.

Adjin-Tettey, supra note 88 at 130. See e.g. Blackwater, supra note 66 at para 4.

Limitation of Actions Act, RSY 2002, c 13, s 2(1)(d) [LAA (Y)].

Limitations Act, 2002, SO 2002, c 24, s 4 [LA (Ont)].

Limitation Act, SBC 2012, c 13, s 3(1)(i); LA (Ont), ibid, s 10(3); LAA(Y), supra note 102, s 2(3).

See e.g. Blackwater, supra note 66 at para 72 (the Supreme Court held there was no non-delegable statutory duty on Canada under the Indian Act, RSC 1985, c I-5 and that fiduciary duties had not been made out in that claim).

See e.g. Indian Residential Schools Re (2000), 268 AR 42 (QB) at paras 68-73.

Oxaal, supra note 6 at 370 ; see also Llewellyn, "Dealing with the Legacy," supra note 87.

Oxaal, ibid at $390 \mathrm{ff}$.

Ibid at 371, 377, citing Blackwater, supra note 66.

Llewellyn, "Dealing with the Legacy," supra note 87 at 276.

Ibid at 279, 281.

Ibid at 280 . 
within a paradigm that does not engage with all of the parties and more specifically with the relationship between them, ${ }^{113}$ or with the deeper issues that are not already part of the legal framework of the dispute framed in tort. ${ }^{114}$ ADR processes are also private and do not "offer a public accounting" of the events and wrongdoings the way court processes do. ${ }^{115}$ This is not to say that ADR mechanisms cannot be crafted to accomplish these goals, but that they must be scrutinized for the same assumptions and flaws as tort litigation.

For her part, Llewellyn advocates for the infusion of restorative justice principles in ADR as a means to avoid the pitfalls of litigation and serve the needs of victims. ${ }^{116}$ Broadly, restorative justice programs seek "to establish or re-establish social equality in relationships" between individual wrongdoers and victims, but also groups and communities, and to look beyond isolated disputes to the underlying conflict and context of the wrongdoing. ${ }^{117}$ Restorative justice principles have been integrated into some traditional justice institutions, most notably the criminal law where sentencing circles and victim impact statements are now integrated. $^{118}$

The strength and the challenge of creating restorative justice programs is that to be successful they must be firmly rooted in the context of the harms and the needs of the specific parties involved, whether they are individuals or entire communities. ${ }^{119}$ Instead of proposing a single design, Llewellyn provides hallmarks for a genuine restorative justice program: it must "involve all parties with a stake in the resolution of the conflict"; it must "recognize and seek to address all the harms resulting from the events"; participation must be voluntary; the process must be premised upon truth-telling with an admission of responsibility by the wrongdoer being a precondition for the process; space for encounter between the victim, wrongdoer, and greater community must be made; and the rights of both victims and wrongdoers must be protected so as to prevent a power imbalance within the process. ${ }^{120}$ Finally, a restorative justice program must include a plan for the future and reintegration of wrongdoers back into the community. ${ }^{121}$

While restorative justice is a dominant paradigm in ADR, corrective justice, which posits that losses are redressed through either return of wrongfully obtained goods or replacement of their value in money or similar goods, can also be applied. For example, the Specific Claims Tribunal of Canada provides monetary award for, for example, the Government's failure to create a reserve of the size promised by treaty, but the Tribunal cannot provide replacement lands. ${ }^{122}$

Criminal Code, supra note 54, ss 717(1), 722(1) (alternatives to sentencing and victim impact statements, respectively).

Llewellyn, "Dealing with the Legacy," supra note 87 at 292.

Ibid.

Ibid at 293.

Specific Claims Tribunal Act, SC 2008, c 22, ss 14, 20. 


\section{b. Alternative Tools}

There are many ADR mechanisms. Those most applicable in the context of the IRS policy are ex gratia payments, public inquiries, and redress programs.

\section{i. $\quad$ Ex gratia Payments}

Ex gratia payments are voluntary payments made under a state's prerogative power to compensate victims for harms suffered. ${ }^{123}$ The state does so when it judges the payments to be in the public interest, and may or may not be pursuant to a clear legal obligation. ${ }^{124}$ Examples include redress payments for Japanese internment during the Second World War ${ }^{125}$ and for persons who received HIV-infected blood. ${ }^{126}$

Ex gratia payments are an interesting alternative to litigation as there are no formal guidelines or legal obligation, and the payments are entirely at the discretion of the government. However, some markers do exist. As noted by the LCC, in every case the victims were blameless, and while the Government was not, or had not yet been found, legally liable for their harms, "there was a nexus between some policy, action or inaction by a public body or publically supported authority and the harm being compensated,"127 that justified the government shouldering the burden of a reparation. The Common Experience Payment ${ }^{128}$ is an example of ex gratia payments used in the IRS context.

\section{ii. $\quad$ Public Inquiries}

Public inquiries are "established to investigate and make recommendations concerning a broad area of public policy" or "to investigate specific events, to make findings about them, and usually to make recommendations about how future occurrences may be prevented."129 Public inquiries regarding federal activities can be instituted under the Inquiries Act, ${ }^{130}$ which allows for the Governor-in-Council to "cause inquiry to be made into and concerning any matter connected with the good government of Canada or the conduct of any part of the public business thereof." 131 Examples include the Royal Commission on Aboriginal Peoples and the ongoing Inquiry into Missing and Murdered Indigenous Women and Girls.

For details of the process in Canada, see Treasury Board of Canada Secretariat, "Directive on Claims and Ex Gratia Payments" (1 October 2009), online: $<$ www.tbs-sct.gc.ca/pol/doc-eng.aspx?id=15782\& section=text $>$ (rescinded as of 29 May 2018). LCC, Report, supra note 34 at 207.

125 Japanese Canadians Ex Gratia Payments Order Authorising the Making of an Ex Gratia Payment to Certain Eligible Persons of Japanese Ancestry as Redress for Injustice suffered during and after World War II, PC 1988-2552 (5 November 1988). See also LCC, Report, ibid at 207. HIV Infected Persons and Thalidomide Victims' Association Orders which Provide for the Making of Ex-Gratia Payments to Individuals who Received HIV-Infected Blood Products and to Individuals whose Mothers Administered Kevadon or Falimol (Thalidomide) and Consequently Suffered Physical Deformities, PC 1990-0872 (10 May 1990), as amended by PC 1991-2543 (16 December 1991). See also LCC, Report, ibid at 207.

LCC, Report, ibid at 208.

For a definition of "Common Expericence Payment," see IRSSA, supra note 2, art 1.01.

LCC, Report, supra note 34 at 249.

RSC, 1985, c I-11.

Ibid, s 2 . 
Public inquiries, while operating under a statutory framework, are not tasked with finding legal liability or guilt, or with compensating victims. Their powers are constrained by the Inquiries Act, ${ }^{132}$ and while their terms of reference may be broad, any inquiry will operate under time and budget constraints that might further limit the scope of its inquiries. ${ }^{133}$ But public inquiries can, through the process of fact finding, which often includes public hearings and media coverage, raise awareness of harms that do not neatly fit into, or span, categories of legal liability. As with ex gratia payments, in opting to create a public inquiry, the government has decided to take on the responsibility of investigating the harm, though not necessarily responsibility for the harm itself.

\section{iii. $\quad$ Redress Programs}

Redress programs are another mechanism that might be offered by a government proactively, or as part of a settlement agreement. ${ }^{134}$ Redress programs provide financial compensation to victims through an ex gratia payment and, like ex gratia payments, the programs do not require a basis in criminal or tort law, though they are often conceived of within the context of litigation. In a redress program, victims undergo a validation process to prove they suffered harm and to justify the amount of compensation. ${ }^{135}$ The program will be specific to the context of the abuse and to the individual's own experience of harm. Redress programs have the capacity to be both comprehensive and flexible in responding to victims' needs, ${ }^{136}$ but this flexibility is often exercised cautiously, with only those harms likely to be proven in court being recognized.

Redress programs are often negotiated with victims to ensure their acceptance but can also be presented as a take-it-or-leave-it alternative to litigation. ${ }^{137}$ The scope of a redress program is specific to the events as well as the willingness of the perpetrator to accept, and the willingness of the victim to settle, specific claims. ${ }^{138}$ The redress itself might also include financial counselling, sponsored therapy, educational counselling or vocational training, and apologies and memorials as well as a simple cash payment. ${ }^{139}$ Redress programs are a tacit recognition that the state has a responsibility to respond to the event and the resulting harms whether it was directly involved or not.

Several redress programs have been crafted to address the IRS legacy including the Independent Assessment Process.

\footnotetext{
132 Ibid.

133 Ibid; LCC, Report, supra note 34 at 250.

$134 \quad$ LCC, Report, ibid at 303.

135 Ibid at 316.

136 Ibid at 304.

137 Ibid at 305. An example is the Jericho Hill School for the Deaf and Blind redress program, which was created after negotiation with some community members but was contested by some victims of abuse at the school and eventually made its way to the Supreme Court of Canada where the program was rejected because its limited scope made litigation the preferable procedure for a fair and efficient resolution of the issues: Rumley v British Columbia, 2001 SCC 69 at paras 35-39. 


\section{b. Assessing the Alternatives}

What all these "alternatives" have in common is that they live on the edge of the preexisting criminal and civil law theories and institutions. Some are directly drawn from those institutions and are simply variations on a theme, and others can be seen as a means to avoid litigation. The LCC considered whether modifications ${ }^{140}$ to the civil and criminal justice systems could be made to make them responsive to victims' needs but concluded, as have I, that

however much these systems are adjusted, the root assumptions upon which they have been developed over the centuries and the constitutional values that have been incorporated into their structure and functioning preclude the kind of comprehensive redesign that would be necessary to respond to survivors' full range of needs. ${ }^{141}$

ADR and other amendments to traditional criminal and civil law responses to harm have been beneficial to many IRS survivors but those mechanisms do not challenge the fundamental principles of individual responsibility found in traditional responses. The traditional and alternative mechanisms have also failed to incorporate the full range of harms stemming from the IRS policy. In particular, none have tackled, in a systematic way, the existence of cultural harm.

\section{MINDING THE GAPS}

Several conclusions can be drawn from the discussion of the criminal, tort law, and ADR mechanisms described above. The first is that they serve different but complementary purposes. Criminal law focuses on state regulation, and punishment, of harmful behaviour by individuals so as to maintain peace and order within society. Tort law and ADR provide forums for individuals and institutions to challenge the harmful actions of others and to seek compensation from them. ADR further allows the parties to tailor processes to context and culture. One way of understanding the difference between the criminal and civil processes is that the criminal law seeks to prevent the commission of crime and denounce the wrongdoer, while the civil law seeks to compensate the victim. ${ }^{142}$ Tort law has also evolved to capture a broader range of harms, and a broader range of wrongdoers, than the criminal law, but it is still limited by certain assumptions that prevent it from recognizing the entire range of harms experienced by IRS survivors and, perhaps more importantly, of drawing society at large into the process. The use of one process does not preclude the operation of the other: an individual can be found liable by a civil court for an act for which she has been found not guilty in criminal court and vice versa. ${ }^{143}$

All these mechanisms are legitimate and useful tools but are limited by their internal assumptions. Two assumptions are particularly problematic when attempting to address the list of harms stemming from the IRS policy. First, these mechanisms, with the possible

\footnotetext{
140 For the LCC's suggested modifications, see their Recommendations in ibid at 403-11.

141 Ibid at 389

142 Manning \& Sankoff, supra note 42 at 29.

143 LCC, Report, supra note 34 at 145. This is because, for example, the criminal standards of proof are generally higher in order to prevent wrongful convictions and infringement of the liberty of the accused.
} 
exception of some negotiated ADR processes, start from the assumption that an individual has committed an act that has caused harm to another individual. In the case of the criminal law the response is to punish the individual. Tort law and ADR have a greater capacity to recognize institutional wrongdoers and multiple levels of responsibility through vicarious liability. However neither of these responses captures me, a non-Indigenous Canadian who had no role in the IRS policy but nonetheless lives in tandem with survivors, their families, and the consequences of the policy, as a responsible party. As the LCC stated:

Civil, and especially criminal, trials are well-suited to dealing with wrongdoings between individuals. Abuse in institutions is, however, rarely just a matter of a single act or the acts of a single person. Even where only one person is alleged to have committed offences, there are usually a number of victims. Where one or more perpetrators have operated within an institution over a period of years, justice usually requires bringing to account not only the actual perpetrator(s), but also those who may have had knowledge of the abuse and could have reported, or put an end to it. In these cases, justice for survivors involves coming to an understanding of the systemic causes of abuse, or the factors that made possible its commission. ${ }^{144}$

Taken one step further, it is not possible in either criminal law or tort law to adjudicate an entire society that allowed a harmful policy to be created and to continue. Nor is it possible for either mechanism to draw me, my family and friends, and the strangers I meet into the process of addressing harm.

The second assumption involves the limit on the recognition of harm. In the words of the LCC there are limits to how well both criminal and civil trials can address the needs of victims of institutional child abuse:

\footnotetext{
Both are adjudicative processes intended to handle all kinds of claims, but their internal procedures make it much easier to pursue certain types of claims. In some cases, these same features may make the process a revictimising experience for those who have already suffered. ${ }^{145}$
}

As I have noted throughout this discussion, criminal and tort law are able to recognize sexual, physical, and some instances of emotional abuse. But they have not, to date, recognized cultural harms, like loss of language and family ties that touched me so deeply during IAP hearings.

In its Report, the LCC identified the importance of these harms to victims:

In any situation, an imposed prohibition against children speaking their mother tongue can be destructive to their sense of identity. Such a prohibition is particularly damaging, however, in oral cultures. Language is the basic medium through which culture is expressed. It helps create and sustain a world view. Removing children from their families, preventing them from speaking their mother tongue and denying them occasions to express their culture through language and associated rituals is a powerful attack on the personal and cultural identity of members of an Aboriginal community. ${ }^{146}$

$\begin{array}{ll}144 & \text { Ibid at } 388 . \\ 145 & \text { Ibid at } 387 . \\ 146 & \text { Ibid at } 61 .\end{array}$


Social and political theorist Rajeev Bhargava gives a poetic and comprehensive description of the importance of culture and the harm it is subject to:

\begin{abstract}
Being a system of meanings, culture is reflected in our conceptual framework, and in our language. Since culture is also a system of evaluation concerning our own life and the lives of others, our action and that of others, an inextricable link exists between culture and ethics. Since religion and ethics are frequently tied to one another and culture is the overarching structure of all meanings, culture is also tied to religion. Thus culture is embodied in the collective memories and future visions of a group, in the group's myths, rituals, rules, norms, and customs. Since all of these - conceptual framework, language, collective memory, future visions, rules, norms and customs, myths and rituals, morality and religion, provide a sense of who we are and our self-worth, culture is inextricably linked to individual and collective identity. Given its importance, every group must have access to its own systems of meanings, interpretations and values, to its tradition and heritage, to its cultures. If members of a group are denied access to their own culture then they suffer cultural injustice. $^{147}$
\end{abstract}

Cultural harm is an important concept because it challenges the understanding of harm currently accepted in the Canadian legal system. ${ }^{148}$ Claims of cultural harm have been made in litigation, but to date have not been recognized by the courts, and the government has stated that "no basis exists at law to found a cause of action for the loss or a diminution of aboriginal language or culture arising from or connected to the operation of an [IRS]."149

In the final analysis, criminal prosecutions and tort litigation are important mechanisms to set and enforce standards of behaviour and to publicly denounce wrongdoers and vindicate victims/survivors. But they are not able to address collective causes or effects of cultural harm. Other solutions are necessary.

\title{
B. DRAWING ON THE Transition
}

Societal conflicts not unlike the IRS policy have occurred in other countries where comparable criminal and tort law systems exist and have similarly been found wanting. In order to solve the limitations of the criminal and tort law responses to harm a series of mechanisms loosely labelled "transitional justice" has developed. As its name suggests, transitional justice is most typically applied in states that are in transition, often from an authoritarian regime to a liberal democratic state following a period of large-scale and intercultural conflict. Transitional justice is thought of as a means by which a society in conflict can establish the rule of law and legitimacy of a government ${ }^{150}$ with the effect of returning or establishing for individuals the status of citizens recognizing them as human beings with

Rajeev Bhargava, "How Should We Respond to the Cultural Injustices of Colonialism?" in Jon Miller $\&$ Rahul Kumar, eds, Reparations: Interdisciplinary Inquiries (Oxford: Oxford university Press, 2007) 215 at $217-18$. Oxaal, supra note 6 at 369 .

Canada (Minister Responsible for Indian Residential Schools Resolution) $v$ The Presbyterian Church in Canada (13 February 2003) Indian Residential Schools Resolution Canada at para 6.2 [emphasis added], cited in Oxaal, ibid at 369 .

150 Jeremy Webber, "Forms of Transitional Justice" in Melissa S Williams, Rosemary Nagy \& Jon Elster eds, Transitional Justice (New York: New York University Press, 2012) 98 at 111. For a general discussion of the evolution of transitional justice from World War II to the present see Ruti Teitel, "Transitional Justice Genealogy" (2003) 16 Harv Hum Rts J 69 [Teitel, "Genealogy"]. 
inherent value. ${ }^{151}$ Transitional justice is therefore complex, operates on a national scale, and is highly particular to the culture and history of a particular conflict.

\section{A CANADIAN APPLICATION}

While the Canadian Government has not been overthrown at the time of writing, these transitional justice mechanisms have obvious value in that they are designed to investigate, recognize, and attempt to address historical and recent harms perpetrated by a state against a minority. The IRS policy caused exactly these types of harm. There is a further dimension to transitional justice that is applicable to Canada: the idea that transitional justice and reparations are part of a broader political project. Even at 150 years, we must realize that as a nation spanning "from coast-to-coast-to-coast," Canada is still in the process of nation building in that Indigenous and non-Indigenous Canadians have not achieved political or social harmony. Consequently, we are still in the process, as are countries in transition, of organizing ourselves internally, and defining ourselves to the rest of the world.

There are two major reasons to consider applying transitional justice as part of this broader political agenda. The first is that the norms of standard legal institutions assume that normbreaking and the resulting harms are rare and exceptional. ${ }^{152}$ They are not designed to address harms that are massive and systemic. ${ }^{153}$ The second is that looking at harm through a political instead of a legal lens allows the participants to pursue ends that are not envisioned by the legal system - ends that go beyond the satisfaction of individual claims, and that involve "recognition, civic trust, and social solidarity." 154 In doing so, we continue our unfinished process of nation building.

\section{NEW(ISH) TOOLS}

Transitional justice makes use of existing legal, political, and social mechanisms but tailors them to the specific events, culture(s), and needs of victims and perpetrators. The most common mechanisms, successor trials, truth commissions, political apologies, compensation, commemoration, and institutional reform are briefly introduced below.

\section{a. Successor Trials}

Criminal justice and the trials of deposed rulers are the original tools of transitional justice. ${ }^{155}$ Successor trials allow the new democratic political order to delegitimize the previous regime. The trial of King Louis XVI of France, and the Nuremberg trials of Nazi leaders are examples of both foundational political acts, and retribution for criminal wrongdoing. ${ }^{156}$ In transitional societies the need to establish order and the desire for retribution and individual accountability must be balanced with the need for legal and cultural renewal, and consideration of collective responsibility. ${ }^{157}$

\footnotetext{
151 Pablo de Greiff, “Justice and Reparations" in Miller \& Kumar, eds, supra note 147, 153 at 160-61.

152 See de Greiff, "Justice and Reparations," ibid at 154

153 Ibid.

154 Ibid at $154-55$

155 Teitel, Transitional Justice, supra note 49 at 27.

$156 \quad$ Ibid at 29.

$157 \quad$ Ibid at 27.
} 
Successor trials must address the problem of holding individuals to account for the crimes of many. The Nuremberg trials set the stage for individual responsibility for mass harms in the aftermath of World War II by eliminating defences based on "acts of state" or "superior orders," 158 but more recent conflicts, the many regime changes in South America and communist Europe in the middle of the twentieth century, for example, did not allow for as clear a demarcation between individual criminal acts or orders, and the complicity of entire structures within the society. In these countries the "feasibility of pursuing [criminal] justice and its ability to contribute to transitional rule of law depended upon the scale of prior wrongdoings, as well as the extent to which they were systemic or state-sponsored." 159 Select individuals might still be prosecuted in exemplary trials to demonstrate that retributive justice is being done, but this selectivity risks threatening the rule of law instead of strengthening it. ${ }^{160}$

The questions asked in recent years highlight a shift in the purpose of transitional justice from the desire to hold a predecessor accountable for harm to the desire to "heal an entire society and incorporate diverse rule-of-law values, such as peace and reconciliation."161 Consequently, successor trials have been overshadowed by other mechanisms such as truth commissions.

\section{b. Truth Commissions}

The current flagship mechanism of transitional justice is the truth commission. Truth commissions are a form of public inquiry, and like public inquiries they vary greatly in scope, purpose, and powers. The mandate of a truth commission may be simply to collect, record, and report on events, while others are tasked with gathering evidence to support prosecution, and still others are created with the expectation of effecting "reconciliation" between victims and perpetrators. The structure will be geared to the purpose(s). The LCC looked briefly at truth commissions in its Report:

\footnotetext{
A truth commission process reflects a conscious renunciation of, and a complete break from, a past when those in authority tolerated, encouraged and even committed massive human rights violations. Its fundamental purpose is to discover the truth and to assemble an accurate and verifiable record of it. Recognising and validating the pain and suffering of survivors and their families becomes a vehicle to promote a collective understanding of past abuse. Together this validation and understanding is seen as the starting point for reconciliation. ${ }^{162}$
}

These multiple goals are not easy to accomplish. In her study of truth commissions world wide, Priscilla Hayner emphasised the difficulties in attempting to "reach and fairly represent 
the stories of thousands upon thousands of victims" ${ }^{\text {"163 }}$ as well as the role of potentially large numbers of perpetrators:

$[\mathrm{T}]$ ruth commissions are of a fundamentally different nature from courtroom trials, and function with different goals in mind. It is also clear that many methodological questions that are central to truth commissions cannot be answered by turning to any established legal norms or general principles, nor can they be well addressed by universal guidelines. Instead, these questions require a consideration of the specific needs and context of each country. ${ }^{164}$

Among these methodological choices are whether to subpoena witnesses or attempt to engage survivors and perpetrators on a strictly voluntary basis, ${ }^{165}$ whether to collect evidence for prosecution or to grant amnesty, ${ }^{166}$ whether to hold public hearings, and whether to name wrongdoers. ${ }^{167}$ These choices are sometimes explicit in the commission's mandate or are arrived at due to pressures of time and budgets. ${ }^{168}$

These methodological choices have implications for the commission's perceived success or failure. In particular, questions of amnesty have led some commentators to argue that truth commissions trade "truth" for "justice," 169 and are a lesser alternative to prosecution only resorted to because of the difficulties in finding the courtrooms, witnesses, lawyers, and time to carry out prosecutions of all the offenders. ${ }^{170}$ Other commentators have noted that truth, as provided by a truth commission, is a necessary precursor to prosecutions and compensation. ${ }^{171}$ Still others have argued that truth commissions are well-suited to the nonretributive needs of victims, including overcoming official denials, record-building, promoting reconciliation, and promoting psychological healing. ${ }^{172}$

Nevertheless, and importantly for this project, a truth commission has the power to unearth and publicise historical events, their causes, and contemporary consequences. It is able to "reestablish a baseline of right and wrong, to humanize the perpetrators, and to obtain and disclose previously hidden information about what had happened."173 The use of a truth commission and the allocation of public funds to address harms is also a signal to all citizens that the subject is national in scope ${ }^{174}$ and should engage their attention regardless of their role in the events. ${ }^{175}$ The Truth and Reconciliation Commission of Canada has written a lengthy report on the legacy of the IRS policy ${ }^{176}$ that addresses the larger history of

Priscilla B Hayner, Unspeakable Truths: Transitional Justice and the Challenge of Truth Commissions, 2nd ed (New York: Routledge, 2011) at 5.

Ibid.

LCC, Report, supra note 34 at 271.

For a survey of the types of truth commissions see Hayner, supra note 163. Ibid at 5 .

Ibid at 76 .

See e.g. Amy Gutmann \& Dennis Thompson, "The Moral Foundations of Truth Commissions" in Robert I Rotberg \& Dennis Thompson, eds, Truth v. Justice: The Morality of Truth Commissions (Princeton: Princeton University Press, 2000) 22 at 22.

Martha Minow, "The Hope for Healing: What Can Truth Commissions Do?" in Rotberg \& Thompson, ibid, 235 at 237.

David A Crocker, "Truth Commissions, Transitional Justice, and Civil Society" in Rotberg \& Thompson, ibid, 99 at 100-101.

Minow, supra note 170 at 253.

Ibid at 249-50.

Llewellyn, "Dealing with the Legacy," supra note 87 at 296.

Ibid at 297.

TRC, Final Report Part 1, supra note 24. 
Canadian-Indigenous relations and the continuing consequences of the IRS policy on the indigenous community.

\section{c. Political Apologies}

Apologies are common tools of transitional justice that have been applied more frequently in litigation in recent years. ${ }^{177} \mathrm{~A}$ political apology is "an official apology given by a representative of a state, corporation, or other organized group to victims, or descendants of victims, for injustices committed by the group's officials or members." ${ }^{\prime 178}$ The political apology is "a mark of respect in the sense that it acknowledges responsibility for a wrong and addresses this acknowledgment to the wronged individual or community." it is a public acceptance of responsibility by the state that is seen as a prerequisite for future harmony in society. ${ }^{180}$ The major goal of an apology is to re-establish a relationship of respect between the parties. ${ }^{181}$ Importantly, the "parties" to an apology can include large numbers of people being represented by the speaker and receiver, recognizing both collective responsibility and collectively experienced harms.

Apologies vary in scope and formality, and are not without controversy. In the case of historical wrongdoing, not all politicians or citizens feel guilt or shame about the events, and consequently they may see no need for an apology. ${ }^{182}$ Others see apologies as a way for the state to by-pass the justice system and the victims' demands for restitution. ${ }^{183}$ Between individuals, apologies often serve to correct a power imbalance, a correction that is not possible between a vulnerable group and a state. ${ }^{184}$ Apologies also carry different weight and require different formalities in different cultures, raising questions about their applicability in a cross-cultural context. ${ }^{185}$ But many authors resist this skepticism and focus on the potential benefits of a properly conceived and delivered political apology. ${ }^{186}$ Matt James has identified eight criteria for an authentic political apology:

An authentic political apology: (1) is recorded officially in writing; (2) names the wrongs in questions; (3) accepts responsibility; (4) states regret; (5) promises nonrepetition; (6) does not demand forgiveness; (7) is not hypocritical or arbitrary; and (8) undertakes-through measures of publicity, ceremony, and concrete influence their use in other contexts, see for example the promotion of apologies in the British Columbia Apology Act, SBC 2006, c 19. But note that there has been little judicial commentary applying these laws to date, and there is no federal apology act that specifically addresses federal government actions at a national level.

Janna Thompson, "Apology, Justice, and Respect: A Critical Defense of Political Apology" in Mark Gibney et al, eds, The Age of Apology: Facing Up to the Past (Philadelphia: University of Pennsylvania Press, 2008) 31 at 31 [Thompson, "Apology"].

Thompson, Intergenerational Justice, supra note 11 at 83.

John Torpey \& Rosa Sevy, "Commemoration, Redress, and Reconciliation: The Cases of JapaneseAmericans and Japanese-Canadians" in John Torpey, Making Whole What Has Been Smashed: On Reparations Politics (Cambridge, Mass: Harvard University Press, 2006) 78 at 83.

Thompson, Intergenerational Justice, supra note 11 at 83.

Thompson, "Apology," supra note 178 at 34.

Alison Dundes Rentlen, "Apologies: A Cross-Cultural Analysis" in Gibney et al, supra note 178, 61 at $72-73$.

Ibid at 70 .

See ibid at 64 .

See e.g. Thompson, “Apology,” supra note 178. 
reparation-both to engage morally those in whose name the apology is made and to assure the wronged group that the apology is sincere. ${ }^{187}$

Political apologies have been employed in non-transitional societies to address (some of) the effects of colonization, including by President Clinton to native Hawaiians, ${ }^{188}$ by Prime Minister Howard to Indigenous Australians and Torres Strait Islanders, ${ }^{189}$ and by Queen Elizabeth II to the Maori people. ${ }^{190}$ The Canadian Government has made two formal apologies for the Indian Residential Schools policy, the first in $1998^{191}$ and a second in $2008 .^{192}$

\section{d. Compensation}

Compensation might take the form of specific restitution like the return of artwork looted by the Nazis, ${ }^{193}$ monetary payments, as were provided by the German Federation to survivors of political persecution by the Nazi government, ${ }^{194}$ or the provision of resources like the 40 acres of land that were ordered to be provided to freed slaves after the American Civil War. ${ }^{195}$

Compensation, especially monetary payments, can be controversial. As John Torpey has written: "[m]oney matters in these contexts, but it is not always clear in what way."196 Viewed cynically, they are a way for wealthy perpetrators to pay off victims, particularly when the power and wealth imbalance in the country remains after the conflict is over. ${ }^{197}$ Compensation for historical events also falls prey to arguments that current taxpayers should not pay for past wrongs or that some of the intended recipients of, for example, restitution for slavery, are actually far better off than some of the taxpayers who would contribute to the compensation fund. ${ }^{198}$

Matt James, "Wrestling with the Past: Apologies, Quasi-Apologies, and Non-Apologies in Canada" in Gibney et al, supra note 178,137 at 139 .

HRJ Res 19, To acknowledge the 100th anniversary of the January 17, 1893 overthrow of the Kingdom of Hawaii, and to offer an apology to Native Hawaiians on behalf of the United States for the overthrow of the Kingdom of Hawaii, 103rd Cong, 1993.

Austl, Commonwealth, House of Representatives, Parliamentary Debates (13 February 2008) at 181 (Mr Rudd, Prime Minister).

Waikato Raupatu Claims Settlement Act 1995 (NZ), 1995/58, s 6.

"Address by the Honourable Jane Stewart Minister of Indian Affairs and Northern Development on the Occasion of the Unveiling of Gathering Strength - Canada's Aboriginal Action Plan" (7 January 1998), online: <https://www.aadnc-aandc.gc.ca/eng/1100100015725/1100100015726>.

Prime Minister of Canada, Stephen Harper, Statement of Apology - to Former Student of Indian Residential Schools (2008), online: <https://www.aadnc-aandc.gc.ca/eng/1100100015644/11001000 $15649>$.

See e.g. "3 Nazi-Looted Artworks Returned in France," CBC News (11 March 2014), online: $<$ www.cbc. ca/news/arts/3-nazi-looted-artworks-returned-in-france-1.2568335>.

United States Department of Justice Foreign Claims Settlement Commission, "German Compensation for National Socialist Crimes" (6 March 1996), reprinted in Roy L Brooks, ed, When Sorry Isn't Enough: The Controversy Over Apologies and Reparations for Human Injustice (New York: New York University Press, 1999) 61 at 61.

Special Field Order No 15 issued by Major-General WT Sherman (16 January 1865), reprinted in Brooks, ibid, 365 at 365 .

Torpey \& Sevy, supra note 180 at 92.

Erin Daly \& Jeremy Sarkin, Reconciliation in Divided Societies: Finding Common Ground (Philadelphia: University of Pennsylvania Press, 2007) at 234.

Think of Oprah Winfrey or Jay-Z. For a point-counter-point on this concern, see David Horowitz, "Ten Reasons Why Reparations for Blacks is a Bad Idea for Blacks - and Racist Too" (2001) 31 Black Scholar 2 at 48; Earl Ofari Hutchinson, "Ten Reasons Why Considering Reparations is a Good Idea for Americans, and Horowitz Too" (30 March 2011), online: <www.mdcbowen.org/p2/rap/ofari.htm>. 
In order to alleviate some of these concerns, proponents of monetary compensation for harms must decide whether to provide compensation to individuals through ex gratia payments or redress programs or to instead put that compensation towards programs or institutions that will benefit the victims as a group. The debate over type of compensation is especially common in cases of historical injustices like slavery, where no direct victims are alive. ${ }^{199}$

The Canadian Government provided compensation for the IRS policy, both to individuals through the Common Experience Payment and collectively through the creation and funding of the Aboriginal Healing Foundation.

\section{e. Commemoration}

Commemoration can take many forms from poetry and ballet performances to parades and monuments, and can be personal, community-based, or national. Commemorative acts or monuments "are among the ways people confront the challenge of responding to trauma"200 in the past and the present. The process of commemoration is important: "[i]t is not simply a case of whether grieving should be private or national, and whose story should be told, but a question of how to negotiate the necessary relationship between them." ${ }^{201}$ The harm recognized, and the person(s) recognized as victims or perpetrators, are negotiated with the development of each act of commemoration. For example, memorials "can name those who were killed; they can depict those who resisted and those who rescued. They can accord honor and confer heroic status; they can express shame, remorse, warning, shock." ${ }^{202}$ The key to meaningful commemoration is the willingness of those involved to enter into deliberations with survivors about what harms need to be recognized, and with ourselves about what role we played then, and can play now, in the commemoration.

Examples of commemoration include a minute of silence, war memorials, and museums that seek to interpret events and to educate future generations about conflict and its aftermath. While those large endeavours are often created by a state or through the work of organizations, other acts of commemoration begin as deeply personal expressions of harm. Poems like "In Flanders Fields" written by John McCrae ${ }^{203}$ about the scenes he saw as a field surgeon in Belgium during World War I offer us insight into the personal experience of harm that we can then connect to our own lives. ${ }^{204}$ But commemoration is not necessarily a tangible object like a statue or a published poem. Australia's "Sorry Day"205 began as a public reaction to the failure of the Australian government to apologize to the "stolen generations" of Indigenous peoples following the recommendation of the 1997 Bringing

Darrell L Pugh, "Collective Rehabilitation" in Brooks, supra note 194, 372 at 372.

Jenny Edkins, Trauma and the Memory of Politics (Cambridge: Cambridge University Press, 2003) at 57.

Ibid at 94 [emphasis in original].

Minow, supra note 170 at 138.

Lieutenant Colonel John McRae, "In Flanders Fields,” online: <www.ndrs.ca/uploads/In\%20Flanders $\% 20$ Fields $\% 20$ Poem.pdf $>$.

Edkins, supra note 200 at $57-58$.

Commonwealth of Australia, Report of the National Inquiry Into the Separation of Aboriginal and Torres Strait Islander Children from their Families (Human Rights and Equal Opportunity Commission: Sydney, 1997), online: <https://www.humanrights.gov.au/sites/default/files/content/pdf/social_justice/ submissions un hr_committee/6 stolen generations.pdf $>$. 
Them Home Report, ${ }^{206}$ which documented the forced removal of Indigenous children from their families. Today, the National Sorry Day Committee is a partnership of indigenous and non-Indigenous Australians and continues to build public awareness of the stolen generations. ${ }^{207}$ This mix of formal and informal, personal and national, means that acts of commemoration can include any type of harm, can recognize any type of responsibility, and can engage anyone willing to look or listen.

Commemoration for the IRS policy is taking shape in Canada with, for example, the establishment of the National Research Centre on Residential Schools and a stained glass window in the parliament buildings.

\section{f. Institutional Reform}

A final relevant mechanism of transitional justice is the promise of institutional reform. Reforms are motivated by the "goals of relegitimizing the State and preventing the recurrence of violence" and are seen as putting words, like apologies, into action to reestablish trust between the state and citizens. ${ }^{208}$ As such, reform is not indicated simply by a taking-up of responsibility for harms in the past, but a promise of nonrepetition in future policies and institutions.

Institutional reform might take the form of minority representation in political structures, purges of corrupt officials from government, the judiciary, and the security services, changes to the land tenure system of the country, or the assurance of economic opportunities for the minority. ${ }^{209}$ The state education system might also be targeted for reform both to remove racist lessons and to "help young people think critically and independently" about harmful events. ${ }^{210}$ The goal of all of these structural changes "should be that all persons, regardless of race, ethnicity, or inherited wealth, should have opportunities to participate politically and live minimally decent lives" ${ }^{\prime 211}$ and avoid recreation of the structures that led to the harms.

In Canada, institutional reform occurred with the end of the IRS policy itself and the closure of the last school in 1996. Other types of reform, like the requirement to include ageappropriate lessons about the IRS policy in school curricula, are being implemented. ${ }^{212}$

\section{g. New Institutional Model}

A second version of institution-based solutions has been put forward by Douglas Sanderson. While still operating within a corrective justice paradigm, this institutional model

"Sorry Day and the Stolen Generations" (updated 22 October 2009), online: Government of Australia $<$ australia.gov.au/about-australia/australian-story/sorry-day-stolen-generations>.

"The History of NSDC," online: National Sorry Day Committee <www.nsdc.org.au/about-us/thehistory-of-nsdc>.

Pablo de Greiff, "The Role of Apologies in National Reconciliation Processes: On Making Trustworthy Institutions Trusted" in Gibney et al, supra note 178, 120 at 133.

International Centre for Transitional Justice, "Institutional Reform," online: $<$ https://www.ictj.org/ourwork/transitional-justice-issues/institutional-reform>.

Minow, supra note 170 at 144.

Crocker, supra note 171 at 107.

See e.g. John Cotter, "Alberta Students to be Taught Legacy of Indian Residential Schools," The Canadian Press (28 March 2014), online: <www.ctvnews.ca/canada/alberta-students-to-be-taughtlegacy-of-indian-residential-schools-1.1750176>.
} 
conceives of reparations for historical injustices as involving assistance with, and support for, the Indigenous institutions that were damaged through the long process of colonization, thereby (slowly) restoring Indigenous communities to the positions of equals within society through their revitalized social and political structures. ${ }^{213}$

While not a prominent model in Canada, several of the Truth and Reconciliation Commission's Calls to Action are reflective of this approach, in particular $\# 14,{ }^{214}$ which calls for language revitalization and $\# 42,{ }^{215}$ which calls for the recognition and implementation of Aboriginal justice systems. Language and law were two aspects of Indigenous peoples' cultures that were harmed by the IRS policy, harms which have not been recognized in Canadian law. With the federal government's commitment to implement the Calls to Action, it is possible that this model will gain importance in coming years.

\section{TRANSITIONAL BARRIERS}

As mentioned above, these mechanisms are not either/or choices for a country in transition to make, but a set of tools to be used in combination to meet the needs of the specific events and communities involved. Looking at transitional justice mechanisms, Pablo de Greiff noted that there is no conflict between different measures, whether they are symbolic or material, individual or collective, when they share the purpose of reconstituting a political community, ${ }^{216}$ so long as the reparations are internally and externally coherent, and do not reproduce or perpetuate unjust social structures. ${ }^{217}$

That is the challenge. Some authors have noted that transitional justice mechanisms may be transitional in name only, falling prey to the dominant concepts of corrective justice and the status quo of unequal relationships in society. Legal concepts of punishment and compensation can pervade the design of ADR and transitional justice mechanisms with pernicious consequences that ignore other needs, like recognition of harm and social solidarity. ${ }^{218}$ For example, restrictions placed on truth commissions in naming perpetrators may be seen as an attempt to promote or maintain the political and legal stability of the previous regime. ${ }^{219}$

There is also a conceptual difficulty in applying transitional justice in a settler-colonial society. As noted above in Part IV.B.2.f (Institutional Reform), transitional justice mechanisms are most often applied to recognize and reform government systems and institutions that caused harm. But transitional justice also assumes that a line has been drawn between the polity at the helm of those systems and institutions, and the polity attempting reparations. In Canada and other settler-polities, this line isn't easily drawn, making it

For a theoretical grounding of this model and further examples, see Sanderson, supra note 8 at $118 \mathrm{ff}$. Truth and Reconciliation Commission of Canada: Calls to Action (Winnipeg: TRC, 2015), online: $<$ trc.ca/assets/pdf/Calls to Action_English2.pdf>; see Bill C-91, An Act respecting Indigenous languages, 1 st Sess, $42 \overline{\mathrm{n}} \mathrm{P}$ Parl, $20 \overline{19}$ (first reading 5 February 2019). Ibid.

See de Greiff, "Justice and Reparations," supra note 151 at 170.

Ibid at 171 .

Ibid at 154

Jeff Corntassel \& Cindy Holder, "Who's Sorry Now? Government Apologies, Truth Commissions, and Indigenous Self-Determination in Australia, Canada, Guatemala, and Peru" (2008) 9:4 Human Rights Rev 465 at $465-66$. 
difficult for present-day actors to identify both the harmful structures and the necessary changes. ${ }^{220}$ This may also help explain my difficulties in returning the gaze of IAP claimants who saw me as the present-day perpetrator of harms suffered before I was born.

But as tools, wielded properly, these institutions are well placed to address a broad range of harms, including cultural harm, because they exist outside of the constraints of legal theories of crime or tort. That said, these mechanisms suffer from the same challenges of completeness and comprehensiveness ${ }^{221}$ as those established systems. Nevertheless, transitional justice offers a means to work through the full range of harms of the IRS policy by avoiding the restrictions of criminal and tort law, while in partnership with them. Through its recognition of a broad range of harms and its goal of pulling together victims and perpetrators, transitional justice provides a means by which Canadians, me, survivors, strangers, can engage with the IRS policy and the roles we all play in its legacy.

But applying one or several of these mechanisms does not guarantee a satisfactory outcome. I participated in IAP hearings where all participants treated the process as a purely tort-based process and others where the atmosphere and goals were palpably restorative or transitional. Both types of hearings succeeded in reaching a settlement and compensation package, but the latter type was far more satisfying to me and, I believe, to everyone else involved. My experience has led me to the conclusion that the success or failure of any dispute resolution mechanism has less to do with the mechanisms themselves than with how we, as individuals and as a society, choose to apply them. I believe those choices are driven by how we understand responsibility for harm.

\section{LOCATING RESPONSIBILITY}

Now we reach a potential solution to my personal dilemma as a Canadian who grew up being, and remains, proud of the accomplishments of my country and who now understands that these accomplishments have cost Indigenous peoples deeply. I have already described how I tie my identity to my grandparents' and parents' choices, and how I feel a responsibility to carry on their traditions. But in order to understand my role as Canada's Representative, I needed to extrapolate that personal call into a civic one. To do so I drew on what I now understand to be theories of responsibility.

There are two branches to the literature on responsibility for large-scale injustices. The first tries to understand responsibility for systemic social injustices like poverty (Young), and the second discusses whether and how to hold present persons responsible for historic injustices like slavery (Torpey, Thompson). Both branches are relevant to this discussion. The work published to date on historical injustice often focuses on the drive to justify reparations for historic wrongs. I bypass that discussion by virtue of the fact that reparations have, in fact, been provided allowing me to focus not on why reparations should be provided, but on who should be engaged in the process. I argue here that the mechanisms we have

220 For a critique of transitional justice in Canada, see Glen Sean Coulthard, Red Skin White Masks: Rejecting the Colonial Politics of Recognition (Minneapolis: University of Minnesota Press, 2014) at $105-10$.

221 For a discussion of these challenges, see Pablo de Greiff, "Introduction" in Pablo de Greiff, ed, The Handbook of Reparations (New York: Oxford University Press, 2006) 1 at 6-10. 
deployed have not engaged citizens with their responsibility to respond to the IRS legacy. This threatens both the legitimacy of the reparations and the possibility of reconciliation.

\section{A. SYSTEMIC RESPONSIBILITY}

One barrier to engaging Canadians in the IRS legacy is the perceived divide between public and personal responsibility for harm. Iris Marion Young provides a way of conceiving of civic responsibility for structural injustices, like poverty, that explicitly addresses this problematic division. Young begins with Hannah Arendt's division of moral, or private responsibility, and political responsibility, which is inherently public and spurs collective action to respond to "historic" events. ${ }^{22}$ Young adopts Arendt's distinction between individual guilt or legal liability, and political responsibility but argues that being born into Arendt's "historical continuum" is an insufficient basis to share in the political responsibility of a community: ${ }^{223}$

To summarize, guilt should be attributed to persons who commit crimes or wrongs, or directly contribute by their actions to crimes or wrongs. Being responsible, but not guilty, is a designation that belongs to persons whose active or passive support for governments, institutions, and practices enables culprits to commit crimes and wrongs. As I read it, this distinction is a matter not of degree but of kind. ${ }^{224}$

This responsibility falls on members of a society by virtue of the fact that they are aware moral agents who ought not to be indifferent to the fate of others and the danger that states and other organized institutions often pose to some people. This responsibility is largely unavoidable in the modern world, because we participate in and usually benefit from the operation of these institutions. ${ }^{225}$

To Young, the standard mode of legal responsibility, the liability model, cannot be extended or adapted to suit structural injustices, but should be reserved for those instances where a causal connection can be made out. ${ }^{226}$ Young reviews, but rejects, the possibility of extending the concept of complicity (like aiding and abetting a criminal) to cover members of society who are complicit in structural injustice (like pollution), arguing that it creates a weaker form of liability and that instead we should create a new, strong, concept of responsibility. ${ }^{227}$ She argues for a taking up of responsibility based instead on our participation "in the diverse institutional processes" 228 that make up a nation and that sometimes produce harm: a responsibility based not merely on membership, but on participation within the polity; an acceptance of the rights and benefits and responsibilities of citizenship. Because responsibility in this model is created by collective actions, it can only be discharged through collective action. ${ }^{229}$

$\begin{array}{ll}222 & \text { Young \& Nussbaum, supra note } 20 \text { at } 89 . \\ 223 & \text { Ibid at } 80 . \\ 224 & \text { Ibid at } 91-92 . \\ 225 & \text { Ibid at } 92 . \\ 226 & \text { Ibid at } 98 . \\ 227 & \text { Ibid at } 104 . \\ 228 & \text { Ibid at } 105 . \\ 229 & \text { Ibid. }\end{array}$


Young further comments on how the liability model is not only inappropriate, but also detrimental in correcting structural injustices:

\begin{abstract}
A blame language can be inappropriate and unproductive in the context of issues of structural injustice because it tends to divide people between powerful wrongdoers and those who are innocent, whether as victims or as bystanders. This often oversimplifies the causes of injustice, and renders most people passive or comparatively unable to help remedy the problem. A rhetoric of blame in politics often seeks to identify one or more particularly powerful actors who have caused the problems, often some public officials. ${ }^{230}$
\end{abstract}

[B]ut if we seek a few powerful actors to blame, we will let many ordinary actors doing their jobs off the hook. A public discourse of blame then oversimplifies, failing to develop a public understanding of the actions and practices whose consequences produce injustice. ${ }^{231}$

Young also notes that the language of blame is likely to produce defensiveness in the population, further paralysing efforts to address the injustice in a forward-looking way. ${ }^{232} \mathrm{As}$ Martha Nussbaum described:

[Young] argues that we ought to distinguish guilt from responsibility. When we apply the concept of guilt to someone, we are blaming them for something that they have done in the past. The function of guilt is to locate fault, to single out for either moral or legal blame, it is usually not appropriate to ascribe guilt to a group as such, unless we have some reason to conceive of the group as a collective agent (as in the guilt ascribed to corporations, for example). Responsibility, by contrast, is a forward-looking concept. To ascribe responsibility to a person is to say that they have a job to do. We can hold either individuals or groups responsible, and responsibility for social ills is typically shared among many agents. People can be responsible without being guilty. ${ }^{233}$

Finding a distinction between guilt and responsibility was the key to my ability to process my emotional and analytical responses to my role as Canada's Representative - to prevent me from being paralyzed by what I heard and by what was expected of me. I felt ashamed, when listening to a claimant's evidence of what government agents had done, but not for myself, and I did not feel guilty. I felt that the claimant and I were on the same side against the often long-dead abuser, and maybe against history itself. In reality my title, "Canada's Representative," was often taken to imply opposition to the claimant's application. Understanding that I could take on responsibility for past Canadians, to be their representative, without also taking on their guilt allowed me to find meaning in the work beyond technical submissions or as penance for my ancestors' wrongdoings.

A second point I find crucial to take away from Young's writing is that the state is not a far away mythical being. As a public servant I am a cog in the wheel of government. More than that, I help guide our public decision-makers through my votes. Political responsibility is our shared public responsibility as members of a collective. The state is often thought of as a dangerous or omnipotent entity when really it is the reflection of its citizens. As Young writes: "we ought to view the coercive and bureaucratic institutions of government as

Ibid at 116 .

Ibid at 117 .

Ibid.

Martha Nussbaum, "Foreword" in ibid at xiv-xv. 
mediated instruments for the coordinated action of those who share responsibility for structures, rather than as distant actors independent of us." ${ }^{.234}$ The state and its citizens alternately lead and push each other through history and neither can take the entirety of the blame or credit for any policy, event, or program. We vote for our government. We, Canadians, are the state and it is untenable for us to continually deny our responsibility for harm and reparations by reassigning that responsibility to the state without recognizing that it was our inaction or reactions that caused the state to act. We are not honest with ourselves until we engage with our own responsibility as the drivers of government action, including the IRS policy.

\section{B. Responsibility for the Past}

The combined consequence of not properly acknowledging individuals' connections with the actions of his or her government and of treating past events as not touching the present leads to apathy and a denial of responsibility among present persons, which is facilitated by the narrow focus of many of our institutions. Nevertheless, Young applied her concept of responsibility to historical injustices without any conceptual difficulty, as have others. Thompson makes the extension from "ancient history" to the present quite simple by stating it as given:

\footnotetext{
Another reason why it is a mistake to marginalise relationships between the generations is that they are not marginal for most people. Citizens commonly locate themselves in a history that concerns itself with the deeds of past citizens. They take pride in their nation's achievements and feel shame for its failures or misdeeds. They regard themselves as inheritors of a valued political tradition that they want to maintain for their successors. ${ }^{235}$
}

Thompson declares that a polity, as an intergenerational agent, as well as acknowledging and carrying on its accomplishments, "is also supposed to take responsibility for injustices of the past: for breaking agreements, committing aggression or for violating the rights of citizens or foreigners." ${ }^{236}$ The responsibility to correct past injustices is inherited along with the society created by our predecessors. ${ }^{237}$ Thompson attempts to override the "legalistic" approach to reparations for historical injustices, which often results in their denial, by calling for a balancing of moral obligations to fulfill past promises and, for example, to ensure an equitable society in the present, ${ }^{238}$ rendering the fact that no one living in the current polity was directly responsible for the harm caused irrelevant. ${ }^{239}$

This approach is not universal. David Miller, in critiquing Thompson's definition of a nation as a body with a continuing set of institutions, prefers the notion of an inherited responsibility. ${ }^{240}$ A nation, which Miller describes loosely as a society outside of its institutions, ${ }^{241}$ inherits responsibility for the wrongs of its forebears through its national

\footnotetext{
234 Ibid at 112

235 Thompson, Intergenerational Justice, supra note 11 at 4.

Ibid at 74 .

Ibid at $77-78$.

Thompson, Taking Responsibility, supra note 12 at xi.

Thompson, Intergenerational Justice, supra note 11 at 79.

David Miller, National Responsibility and Global Justice (Oxford: Oxford University Press, 2007). Ibid at 143 .
} 
inheritance: the benefits they enjoy from the "physical, human, and cultural capital accumulated by previous generations." 242

However conceived, national identity plays a role in understanding the causes of harm and potential reparations. Danielle Celermajer, writing about Australia, points to the political culture of a nation as a pre-condition to harms in settler societies: "The pervasive racism against Aboriginal people, the political imperative of delegitimizing Aboriginal people as competent citizens and beyond this the denial of legitimate Aboriginal law and sovereignty were all conditions of possibility for the specific acts." 243 Similarly, in its Report, the LCC stated: "It bears repeating that a culture of abuse requires an enabling environment within which to flourish." ${ }^{244}$ While the LCC was speaking about specific institutions, it is also true that without general acceptance of the view that Indigenous peoples were inferior, the Canadian IRS policy would not have been instituted or continued.

Celermajer, echoing Young, identifies the classical liberal fear of collapsing the individual into the collective through this equating of societal responsibility with specific politically authorized acts ${ }^{245}$ as one barrier to accepting responsibility. She proposes that through a discourse theory in which national culture and the nation "mutually construct and constrain" 246 one another, the problem can be resolved:

\footnotetext{
The members of the collective are thus not implicated as they would be were a linear causal model at work, moving from people's ideas or consciousness via their actions to breaches of the law - a model that forms the basis for criminal guilt. Rather, people, along with a range of institutions, are the source and the site of the political culture within which it is possible for the wrongful actions to occur... They cannot be abstracted and blamed; but nor are they automata, merely passive recipients of institutionalized norms. ${ }^{247}$
}

This conception brings the responsibility for harm out of the individual's guilt and recognizes the underlying communal culture that led to the wrong: "By linking the members of the nation to shame and responsibility via political culture and the production of the conditions for the original political action (removal), one produces a justification for political action (the apology)., 248

Unfortunately, this move from individual to collective shame does not dismantle the linguistic barrier to taking up responsibility for harms. To counter this difficulty, Torpey proposes a shift in language from perpetrators to beneficiaries: claims are not being made by the victim against the wrongdoer, but by and to their descendants. ${ }^{249}$ Building on Torpey's proposal, Paulette Regan looks beyond a shift in terminology to propose a shift in our

Ibid at 160 .

Danielle Celermajer, "The Apology in Australia: Re-covenanting the National Imaginary" in Elazar Barkan \& Alexander Karn, eds, Taking Wrongs Seriously: Apologies \& Reconciliation (Stanford: Stanford University Press, 2006) 153 at 162.

LCC, Report, supra note 34 at 14.

Celermajer, supra note 243 at 167

Ibid at 169 [emphasis in original].

Ibid.

Ibid at 172; see also Elazar Barkan, "Introduction: Reparation: A Moral and Political Dilemma" in Miller \& Kumar, supra note 147,1 at 3.

John Torpey, "Introduction: Politics and the Past" in John Torpey, ed, Politics and the Past: On Repairing Historical Injustices (Lanham, Md: Rowman and Littlefield, 2003) 1 at 18. 
understanding of our national myths. She looks to incorporate the effects of the harms Indigenous Canadians experienced on non-Indigenous Canadians' national identity. To Regan, the current failure to understand and accept a shared responsibility as beneficiaries of historical injustice is a "violent innocence" whereby the current generation is made a victim of the past policies and practices enacted for his or her benefit and therefore separates his or herself from both survivors and political ancestors: ${ }^{250}$

Dealing with legal claims based on the actions of individuals is a matter of criminal or civil justice. But when the benefits, privileges, and wealth that colonizers have reaped from Indigenous lands and resources are factored in, the stakes become significantly higher. It is this "link between conquest and dispossession, between racialized power and racialized privilege, between perpetrator and beneficiary," that must be made more visible and taken into account. ${ }^{251}$

For both Regan and Torpey the shift from perpetrator to beneficiary spans the long gap between historical injustice and the present-day consequences of colonialism. This is the struggle I experienced while trying to place myself within the IRS legacy.

In making this analysis the extraction of the IRS policy from the broader process of colonialism is revealed to be artificial. How did I benefit from the IRS policy? Taking a long view, the policy benefitted very few Canadians, Indigenous or non-Indigenous. But it was intended to benefit all Canadians by creating a homogenous population that would participate in the growing Canadian economy. It is as a tool of colonialism that the IRS policy was meant to benefit the country and its citizens into the future. I am one of those future citizens who was born on and live on this territory because of the fact of colonialism. The benefit to me is the place of my birth, my childhood, and my home. As is yours.

But even once this status as a beneficiary is acknowledged, the difficulty remains that because no individual perpetrator is alive to take the blame, individuals within a polity are likely to accept that someone should do something, without engaging with their own role in either the harm or the reparation. We expect the state to step in, but are not interested in sacrificing our own privileges or benefits to complete the task. This is the same space Young addressed when looking at structural injustices that are contributed to by individuals diligently following the law ${ }^{252}$ — when our actions are morally blameless but nonetheless result in harm. To help avoid this paralysis, Young cautions against reducing the concept of collective action to "government action":

Politics in this sense often includes government action but is not reducible to it. Contemporary theories of justice, along with much popular opinion, tend to assume that remedy for injustice is the responsibility of a particular agent, the state, and that the responsibility of citizens is to make claims upon government to bring about justice. It is often true that the best or only way for social actors to organize collective action to redress injustice is by means of state institutions. However, we ought to view the coercive and bureaucratic institutions of government as mediated instruments for the coordinated action of those who share

$250 \quad$ Regan, supra note 3 at 34-36.

251 Ibid at 36-37 [citations omitted] [emphasis in original].

252 See her example of "Sandy" in Young \& Nussbaum, supra note 20 at $46 \mathrm{ff}$. 
responsibility for structures, rather than as distinct actors independent of us. Government policy to promote social justice usually requires the active support of communities to be effective. ${ }^{253}$

While the state might be best placed to provide reparations for harms, particularly harms that were experienced by a large portion of the population, we must be careful that the intention behind the reparations is not undermined by a polity foisting responsibility onto its government without engaging with it individually.

\section{Conclusion}

Thompson, Young, Torpey, and others have put forward concepts of responsibility that are premised upon intergenerational or collective awareness. The process of taking up responsibility removes many of the barriers to recognizing obligations for acts that were not committed by present individuals, by you or me. They have addressed my own distress and confusion when acting as Canada's Representative. I had jumped into the IAP, into the reparations for the IRS legacy, without considering the foundation of the IAP or the IRS policy, and was unprepared for the result.

As I stated above, it was a shift in thinking — from criminal guilt and tort liability that I could not agree to take on, to a generalized responsibility as a citizen to recognize and participate in the IRS legacy — that allowed me to engage with claimants as Canada's Representative, instead of acting as an aloof lawyer or being overwhelmed by an assumption of guilt.

That said, each hearing was different. Each contained a different combination of individuals, a different setting, a different story, though some people, notably claimant's counsel and adjudicators, became familiar, as did many stories. My personal understanding of my responsibility as Canada's Representative and a Canadian citizen required me to respond differently to each claimant depending on their experience of harm, their expectations of me, and their expectations of the process. I didn't always get it right. Remembering this variety of experiences makes me hesitant to declare that one author or one concept of responsibility applies perfectly to the IRS legacy and how Canadians should address it. While I know which concepts allowed me to maintain my sense of self and integrity during hearings, my approach was not the approach every claimant needed to see or hear. And my approach would overwhelm some of those who act as Canada's Representative, the same as their approaches risked overwhelming me. The one aspect I do believe can be generalized is the move Young advocates, and Torpey and Regan name, from guilt and blame as individuals to a broad assumption of responsibility for harm based on our status, as Canadians, as beneficiaries of the process of colonialism; the IRS policy being one element of colonialism that brought me, adjudicators, claimants, and their counsel into close context during IAP hearings. As that one element caused significant harms, it is our responsibility as beneficiaries to respond, as best possible, to those harms.

I now understand how elements of restorative justice, transitional justice, social justice, intergenerational responsibilities, and collective responsibility as well as criminal and tort 
law mechanisms, all apply to the IRS legacy. Individual abusers who are still living should face criminal prosecution and punishment for the harms they caused. School administrators, church groups, and government agencies should be made to compensate victims for their negligence. But we have not discharged our responsibility to each other as citizens until we have recognized the full range of harms stemming from the IRS policy. So, while Canada is not a country in transition as usually understood, the mechanisms of responsibility developed in transitional justice to recognize historical injustice and mass harm do apply. But even these mechanisms for engagement and reparation will not assist us in achieving reconciliation or even simple reparation if we do not turn our minds to our responsibility as Canadians to recognize harms and select and design our mechanisms accordingly. We must do so for both political and moral reasons: "because [we] recognize that the historical injustices continue to impact not only the well-being and identity of the victims but also on [our] own identity as perpetrators," as beneficiaries of the harmful policies. ${ }^{254}$

Returning to where this inquiry started, I now recognize that I struggled with my role within the IAP because the stated goals of the process did not correspond to what I understood to be the needs of survivors or of my own need to connect with survivors and others about how the IRS legacy has affected all Canadians. But in the end, this research is not about the IAP, or even about recognizing harm. It is about how Canadians, individually and as a society, understand our history and our place within it. If every person I had met outside or inside of the IAP had approved of the process, I might have accepted the limitations of its tort-law approach. But instead, I faced conflict from people who felt like the IAP was too much of a remedy as well as from people who felt it was too little. The lack of a consistent understanding of the process led me to wonder if my concerns with the IAP were due less to the structures of the institution or the remedy it provided than with our understanding, or our lack of a collective understanding, of not only what harm was being remedied but of why it should be remedied. This is because we have not, as a society, engaged in a discussion of what the IRS policy means to Canada.

This article does not address the provision of remedies or make any pronouncement as to what remedy will be sufficient to compensate victims. Some losses simply cannot be repaired - there is no way to resurrect a lost language - and financial compensation, of any amount, will never erase the memory of being raped. At the same time, for Canada to continue as a country, there must be some finality to the reparations (in whatever form) provided. My goal has been to outline the conversation I believe is a necessary discussion of how to fulfill our responsibilities as Canadians. 